\title{
Replacing concentrates with a high-quality hay in the starter feed in dairy calves: I. Effects on nutrient intake, growth performance, and blood metabolic profile
}

\author{
G. Terler, ${ }^{1 *} \boldsymbol{\dagger} \odot$ G. Poier, ${ }^{2 *} \odot$ F. Klevenhusen, ${ }^{3} \odot$ and Q. Zebeli ${ }^{2} \odot$ \\ ${ }^{1}$ Institute for Livestock Research, Agricultural Research and Education Centre Raumberg-Gumpenstein, 8952 Irdning-Donnersbachtal, Austria \\ ${ }^{2}$ Institute of Animal Nutrition and Functional Plant Compounds, Department for Farm Animals and Veterinary Public Health, \\ University of Veterinary Medicine Vienna, 1210 Vienna, Austria \\ ${ }^{3}$ German Federal Institute for Risk Assessment, Department Safety in the Food Chain, 10589 Berlin, Germany
}

\begin{abstract}
Concentrate-rich starter feeds are commonly fed to dairy calves to stimulate early solid feed intake and growth performance; yet, starter feeds lacking in forage fiber may jeopardize gut development. This research primarily aimed to test a complete or partial replacement of concentrates with hay of different qualities in the starter feed on nutrient intake, growth performance, apparent total-tract digestibility (ATTD) of nutrients, and blood metabolites in dairy calves. Immediately after birth, 40 Holstein Friesian calves were randomly allocated to 1 of 4 starter diets, which differed in hay quality and concentrate inclusion $[\mathrm{MQH}=100 \%$ medium-quality hay, 9.4 MJ of metabolizable energy (ME), $149 \mathrm{~g}$ of crude protein (CP), $522 \mathrm{~g}$ of neutral detergent fiber $(\mathrm{NDF}) / \mathrm{kg}$ of dry matter $(\mathrm{DM}) ; \mathrm{HQH}=100 \%$ high-quality hay, 11.2 MJ of ME, $210 \mathrm{~g}$ of $\mathrm{CP}, 455 \mathrm{~g}$ of $\mathrm{NDF} / \mathrm{kg}$ of $\mathrm{DM} ; \mathrm{MQH}^{+} \mathrm{C}=30 \%$ medium-quality hay $+70 \%$ starter concentrate; $\mathrm{HQH}^{+} \mathrm{C}=30 \%$ highquality hay $+70 \%$ starter concentrate]. The concentrate consisted mainly of grains, oilseeds, and mineral supplements (13.5 MJ of ME, $193 \mathrm{~g}$ of CP, $204 \mathrm{~g}$ of $\mathrm{NDF} / \mathrm{kg}$ of $\mathrm{DM}$ ). Calves were used in the experiment from d 1 to 99 of life. During the first 4 wk, all calves were fed acidified whole milk ad libitum, and afterward they were gradually weaned from wk 5 to 12 . Calves had ad libitum access to their starter diets and water throughout the experiment. Milk, water, and solid feed intake was recorded daily, live weight was measured once a week, and blood samples were collected on d $1,3,7,21,49,77$, and 91 and analyzed for selected metabolites. The ATTD was measured in wk 14 of life. Total DM intake and daily weight gain of calves were not affected by the starter feed during the first $8 \mathrm{wk}$
\end{abstract}

Received July 28, 2021.

Accepted October 22, 2021.

*These authors contributed equally to this work.

†Corresponding author: georg.terler@raumberg-gumpenstein.at of life. However, from wk 9 to 14, calves fed the MQH diet had lower DM, ME, and CP intake and gained less weight than calves from the other experimental groups. Feeding the $\mathrm{HQH}$ diet resulted in similar $\mathrm{CP}$ and $\mathrm{ME}$ intake and growth performance compared with calves receiving diets containing concentrates. Furthermore, feeding the HQH diet improved the ATTD of NDF, resulting in similar ATTD of organic matter with the $\mathrm{HQH}^{+} \mathrm{C}$ and $\mathrm{MQH}^{+} \mathrm{C}$ groups. Interestingly, calves fed the $\mathrm{HQH}^{+} \mathrm{C}$ diet showed less sorting for concentrate, compared with the $\mathrm{MQH}^{+} \mathrm{C}$ group. Concentration of blood metabolites, including glucose, lactate, insulin, nonesterified fatty acids, triglycerides, and total protein, did not differ after the first week of life. However, serum $\beta$-hydroxybutyrate was higher in calves fed the $\mathrm{HQH}$ diet starting from wk 11. Both groups fed the hay-only diets maintained higher cholesterol levels after weaning compared with the groups fed hay-concentrate mixtures. In conclusion, feeding high-quality hay can fully replace starter concentrates in the feeding of dairy calves without adverse effects on performance during the rearing period, while increasing forage fiber intake and utilization, which enhanced ruminal ketogenesis and cholesterogenesis around weaning. Further research is needed to evaluate long-term effects of feeding highquality hay on health and development of dairy calves, especially in terms of the observed improvements in ruminal ketogenesis and cholesterogenesis around weaning.

Key words: hay quality, calf rearing, feed intake, weight gain, calf metabolism

\section{INTRODUCTION}

Feeding of calves during the preweaning period is crucial for the entire productive cycle of dairy cattle. Not only is early nutrition important for the metabolic programming of the dairy calf (Opsomer et al., 2016), the transition from milk-based to more solid feed intake during the preweaning period sets the course for the 
animal's adequate development and health. Indeed, early and high intake of solid feeds maintains growth performance of dairy calves while promoting the development of the digestive tract, especially of the rumen (Baldwin et al., 2004; Castells et al., 2013; Khan et al., 2016). In modern dairy calves, both early development of the digestive tract and growth performance to reach breeding targets are of special importance. Taking into account the common breeding strategy in dairy cattle, which includes insemination of dairy heifers for the first time at 14 to $16 \mathrm{mo}$, with 60 to $65 \%$ of adult BW (Fricke, 2004), dairy calves must reach a growth rate of 700 to $900 \mathrm{~g} / \mathrm{d}$ during the rearing period.

To achieve this, soon after birth, calves are fed starter feeds, commonly made of highly palatable and digestible ingredients such as cereal grains and oilseeds. This allows smoother transition from milk to solid feed and enhances the solid feed intake. However, such ingredients in the starter feed lack physically effective NDF, which the young ruminant needs for early development of the rumen and its digestive processes (i.e., volume, muscles, pillars, stratification, and fermentation; Khan et al., 2016). Fiber-rich feed sources are commonly considered to be less palatable and not preferred by young calves, jeopardizing their early intake and the afore-mentioned rumen development. To overcome this, calves are fed dry TMR as starter diet, comprising concentrates rich in energy and nutrients, and low amounts of fiber-rich forages (e.g., straw, hay; Aragona et al., 2020; Mitchell and Heinrichs, 2020).

However, despite little inclusion of forages, starter feeds are mainly starch-rich and highly fermentable in the rumen, known to increase risk of ruminal and metabolic health issues in ruminants. Even when offered as dry TMR, calves might sort against less palatable forages, especially after weaning (Miller-Cushon et al., 2013; Miller-Cushon and DeVries, 2015; Engelking et al., 2020). Studies with adult cattle have repeatedly shown that feeding high amounts of starchy concentrates increases the risk of ruminal acidosis (Plaizier et al., 2012; Zebeli and Metzler-Zebeli, 2012) and causes major shifts in the microbial population in the rumen, commonly in favor of amylolytic and against fibrolytic microbiota (Petri et al., 2013; Wetzels et al., 2016). Similar results have been reported in young rearing calves fed starch-rich starters (Terré et al., 2015; Khan et al., 2016).

Research in adult cattle has also shown that using forages with high quality has the potential to replace concentrates in the diet for dairy cattle. When harvested at an early maturity stage and dried indoors, the harvested forages are rich in water-soluble carbohydrates (WSC) and other nutrients such as CP and micronutrients. In addition, they are aromatic and pal- atable and stimulate feed intake, while still maintaining a high level of physically effective NDF. For example, feeding WSC-rich grasses or hay to dairy cows increased DMI as well as DM and nutrient digestibility compared with conventional grasses or hays (Moorby et al., 2006; Kleefisch et al., 2017). Furthermore, Klevenhusen et al. (2017) found significant improvements in ruminal microbial populations in favor of fibrolytic bacterial community and NDF digestibility when cows were fed WSC-rich hay instead of any hays with concentrates. Feeding WSC-rich grasses also had an increasing effect on feed intake of steers (Lee et al., 2002) and daily gains in lambs (Lee et al., 2001).

The potential of feeding such high-quality hay to calves and its potential to replace common starter concentrates have not been evaluated yet. Therefore, this research primarily aimed to test a complete or partial replacement of starter concentrates with hay of 2 different qualities on feed and nutrient intake, growth performance, apparent total-tract digestibility (ATTD) of nutrients, and blood metabolites in calf rearing. We hypothesized that high-quality hay, rich in WSC and $\mathrm{CP}$, with high degradability and digestibility, can fully replace concentrate-rich starter feeds in dairy calves without adverse effects on feed and nutrient intake, daily gain performance, and plasma metabolic profile during the rearing period.

\section{MATERIALS AND METHODS}

\section{Animals, Housing, and Dietary Treatments}

The experimental protocols were approved by the national authority according to $\S 26$ of the Law for Animal Experiments, Tierversuchsgesetz 2012-TVG (GZ: BMBWF-66.019/0016-V/3b/2019). The feeding experiment was conducted at the Agricultural Research and Education Centre Raumberg-Gumpenstein (Irdning-Donnersbachtal, Austria, $\left.47^{\circ} 30^{\prime} \mathrm{N}, 14^{\circ} 6^{\prime} \mathrm{E}\right)$. We performed an a priori power analysis to estimate the sample size in this experiment with the Proc Power of SAS version 9.4 (SAS Institute Inc.). For this, we used nutrient intake and digestibility as response variables. In the power analysis, we assumed that a difference with biological relevance between the control and respective treatments would occur if the effect size $\mathrm{F}$ ranged between 0.6 and 1 for an expected standard variation of around 0.3 . The power analysis indicated that the use of 10 biological replicates per group provides sufficient power (power $1-\beta$ error probability of $>90 \%$ with $\alpha$ $=0.05)$ to reject the null hypothesis, $\mathrm{H}_{0}$, if this were true. Therefore, a total of 40 Holstein Friesian calves (20 males, 20 females) were used in this experiment, which lasted from March 2019 until September 2020 
and covered d 1 to d 99 of life. Immediately after birth, calves were randomly allocated to 1 of 4 experimental groups ( $\mathrm{n}=10$ calves per group) to obtain 4 groups balanced by birth weight $(42.9 \pm 6.2 \mathrm{~kg})$ and sex.

The experimental design consisted of a $2 \times 2$ factorial arrangement of dietary treatments (i.e., 2 hay qualities and 2 different concentrate levels). This allocation of the dietary factors yielded the following 4 starter diets: (1) 100\% medium-quality hay without concentrate (MQH); (2) 100\% high-quality hay without concentrate (HQH); (3) 30\% medium-quality hay and $70 \%$ concentrates $\left(\mathbf{M Q H}^{+} \mathbf{C}\right)$; and (4) $30 \%$ high-quality hay and $70 \%$ concentrates $\left(\mathbf{H Q H}^{+} \mathbf{C}\right)$. These starter feed treatments were offered to the calves ad libitum during the entire experimental period. The MQH was a second-cut hay harvested from permanent grassland at Agricultural Research and Education Centre Raumberg-Gumpenstein at ear emergence and dried indoors using a roof solar collector combined with a heat pump dehumidifier (HSR Heutrocknung SR GmbH). The permanent grassland consisted of approximately 75\% grasses (mainly Alopecurus pratensis, Dactylis glomerata, Festuca pratensis, and Trisetum flavescens), $15 \%$ clover (mainly Trifolium repens), and $10 \%$ herbs (Klingler et al., 2020). The HQH was produced in the Austrian federal state Vorarlberg (Rhine valley) and consisted mainly of Lolium perenne. It was a mixture of first- and second-cut hay, which was harvested at the beginning of ear emergence and dried indoors. Details of the $\mathrm{HQH}$ harvest and drying procedures used are given in Kleefisch et al. (2017). Both hays were chopped to approximately $4.0-\mathrm{cm}$ particle length before feeding. The starter concentrate consisted of $36 \%$ ground wheat, $35 \%$ ground barley, $17 \%$ soybean meal, $10 \%$ linseed meal, and $2 \%$ mineral premix.

Housing. Calves were born in special-needs boxes for cows at the research farm of Agricultural Research and Education Centre Raumberg-Gumpenstein. Immediately after birth, calves were fed warm colostrum from their dams ad libitum (minimum $2.5 \mathrm{~L}$ ) via a bottle. Afterward calves were brought to individual boxes for calves, equipped with straw. Calves were kept in individual boxes for the whole experiment, but the size of the boxes was adapted according to the Austrian regulation for animal husbandry (1. Tierhaltungsverordnung) based on live weight of calves. Fresh straw was added each day, and construction of boxes allowed visual contact with other calves. Due to health problems, which were not related to the experimental setup, 2 calves ( 1 female of the MQH group and 1 male of the $\mathrm{MQH}^{+} \mathrm{C}$ group) had to be removed from the experiment before the planned end at d 99 of life. These calves were not included in data analysis.
Feeding. Starting from d 2 of life, all calves from the 4 experimental groups were offered acidified milk according to the same milk feeding regimen. All calves had access to milk in a milk feeding bucket with teat the whole day, and fresh acidified milk was provided twice per day at $0600 \mathrm{~h}$ and $1700 \mathrm{~h}$. For acidification of the milk, approximately $0.1 \%$ of $85 \%$ formic acid were added to raw whole milk to reach a $\mathrm{pH}$ of 5.5. During the first 4 wk of life, all calves had ad libitum access to acidified milk. In wk 5 and 6 , milk allowance was limited to $8 \mathrm{~kg}$ of acidified milk per day, and, from wk 7 on, daily milk supply was reduced by $1 \mathrm{~kg}$ each week. Calves were weaned at the end of wk 12 , so that in the last 2 experimental weeks (i.e., wk 13 and 14), calves were fed the experimental solid feeds and water only. Calves had ad libitum access to solid feed in separate feeders and fresh water (in buckets) from day of birth onward. Fresh solid experimental feeds and water were provided once a day in the morning and, in case of high water intake, also in the evening. Amount of offered milk, solid feed, and water, as well as residues, were recorded at each feeding event using a digital balance (DMA02 Baby, Gassner Wiege- und Messtechnik $\mathrm{GmbH})$. Hays and starter concentrate were separately weighed in and mixed afterward for the $\mathrm{MQH}^{+} \mathrm{C}$ and $\mathrm{HQH}^{+} \mathrm{C}$ groups once daily before being fed to the calves. After recording, the feed residues of both groups were sieved (screen size: $5 \mathrm{~mm}$ ) to separate hays from starter concentrate, and in this way the intake of hay and concentrate as well as feed sorting behavior of the calves were recorded by difference. Body weight of calves was measured on the first $4 \mathrm{~d}$ of life and subsequently once a week using a cattle scale (maximum weight $500 \mathrm{~kg}$; Ortner). Empty BW at the end of the experiment (d 99 of life) was calculated using the equations published by Jahn and Chandler (1976).

\section{Sampling Procedures}

Feed Samples. Once a week, samples of MQH, $\mathrm{HQH}$, and concentrate mixture were collected, and DM concentration of samples was analyzed by drying in a forced-air oven (FD/FED 720, WTB Binder Labortechnik $\mathrm{GmbH}$ ) for $24 \mathrm{~h}$ at $105^{\circ} \mathrm{C}$. Furthermore, samples of 4 consecutive weeks were pooled for chemical analyses. Before chemical analyses, samples were ground to pass through a 1-mm screen (mill: custom-made product, Kurz Altaussee $\mathrm{GmbH}$ ). Chemical analyses were carried out using VDLUFA (2012) methods (DM: method 3.1; CP: 4.1.2; ether extract: 5.1.1; ash: 8.1; NDF: 6.5.1; ADF: 6.5.2; ADL: 6.5.3; enzyme-soluble OM: 6.6.1; HCl-insoluble ash: 8.2). The concentration of NFC in feeds $(\mathrm{g} / \mathrm{kg}$ of DM) was calculated according to Sniffen 
et al. (1992). The ME concentration of feeds was calculated based on chemical analysis, using equations published by GfE (2008) for hay and by GfE (2009) for concentrates. Data for milk composition were generated from milk samples, which were routinely collected by the common milk analyses at least 3 times per month. These samples were analyzed at a local laboratory (Qualitätslabor Österreich, St. Michael, Austria) using mid-infrared spectroscopy. The ME content of milk was calculated using the results of these analyses, digestibility coefficients for milk (DLG, 1997), and the equation published in GfE (2001). The WSC, ethanol-soluble carbohydrates, and fructans in hays were analyzed using an ELISA Reader (625 nm, Microplate Absorbance Spectrophotometer, Bio-Rad $\mathrm{GmbH}$ ) and calculated according to the method published by Yemm and Willis (1954) and adapted by Greger et al. (2018).

Feces Samples. In wk 14, feces samples were collected for $7 \mathrm{~d}$ in the morning and in the evening. These samples were pooled and used for determination of DM concentration and chemical analyses. Before chemical analyses, feces samples were dried at 50 to $55^{\circ} \mathrm{C}$ in a forced-air oven for $72 \mathrm{~h}$ and ground through a 1-mm screen. The equipment used for drying and grinding, as well as the methods used for chemical analyses, were the same as described for feed sample analyses. The only difference was that fecal nitrogen and protein content was analyzed in fresh sample material to prevent nitrogen losses during the drying process using method 4.1.1 described by VDLUFA (2012). Based on concentration of nutrients and $\mathrm{HCl}$-insoluble ash (indigestible marker) in feeds and feces, apparent digestibility was calculated according to Kirchgessner et al. (2008).

Blood Samples. Blood samples were collected on d $1,3,7,21,49,77$, and 91 . Blood was sampled within $6 \mathrm{~h}$ from birth at $\mathrm{d} 1$, and subsequent samples were always taken at $0600 \mathrm{~h}$. Samples were collected from the jugular vein using $0.9-\mathrm{mm} \times 38$ - $\mathrm{mm}$ multiple sampling cannulas, 9-mL serum evacuated tubes, and 6-mL evacuated tubes containing sodium fluoride and potassium oxalate (Vacuette, Greiner Bio One International $\mathrm{GmbH})$. The samples were allowed to clot for $1.5 \mathrm{~h}$ at room temperature and were centrifuged at 3,000 $\times g$ for $20 \mathrm{~min}$ at $20^{\circ} \mathrm{C}$ (Centrifuge 5702, Eppendorf AG). Serum and plasma were stored in 2-mL tubes (SafeSeal reaction vessel, Sarstedt AG \& Co KG) at $-80^{\circ} \mathrm{C}$ until analysis. Concentrations of glucose and lactate in plasma and nonesterified fatty acids (NEFA), BHB, cholesterol, total protein, and triglycerides in serum were analyzed using standard enzymatic colorimetric assays with a fully automated analyzer for clinical chemistry (Cobas 6000/c501, Roche Diagnostics GmbH) at the laboratory of the Central Clinical Pathology Unit, University of Veterinary Medicine, Vienna, Austria. Serum concentrations of insulin were measured with an xMark Microplate Absorbance Spectrophotometer (Bio-Rad Laboratories GesmbH) using respective methods and kits (Mercodia Bovine Insulin ELISA, Mercodia AB).

\section{Statistical Analysis}

Statistical analysis was performed using SAS version 9.4 (SAS Institute Inc.). Normal distribution of data was tested using PROC UNIVARIATE. As data on DM and nutrient intake were not normally distributed, the whole data set was divided into 3 data sets based on weeks of life (data set 1: wk 1-4 of life; data set 2: wk 5-8 of life; data set 3: wk 9-14 of life), which were analyzed separately. Furthermore, separated data sets were transformed using square root or logarithm to obtain normally distributed data. The ANOVA was performed using PROC MIXED of SAS. The model for analysis of DM and nutrient intake, live weight, daily gain, and blood metabolites consisted of the fixed effects of hay quality, concentrate inclusion, and their interaction, as well as calf age (week or day of life), sex, and corresponding interactions. Calves within the experimental groups were considered as random effects. Furthermore, measurements taken on the same calf in different weeks or days were considered repeated measures in the ANOVA using the variance components covariance structure, which was chosen based on Akaike information criterion. In the analysis of ATTD, birth weight, final $\mathrm{BW}$, and final empty $\mathrm{BW}$ (and respective daily gains), the fixed effects of hay quality, concentrate inclusion, and their interaction, as well as the sex and the corresponding interactions were tested. Multiple comparisons of least squares means were performed with the Tukey test. Significant differences were assumed if $P$-values were below 0.05 . Milk and water intake were not normally distributed even in separated and transformed data sets, and were therefore not statistically analyzed and are presented only in a descriptive form.

\section{RESULTS}

\section{Nutrient Composition of the Hays and Diets}

As expected, the nutrient analysis showed different composition in various nutrients between the 2 hays (Table 1). Compared with MQH, HQH was characterized by a higher CP concentration and lower contents of NDF, ADF, and ADL, resulting in a higher ME content. The high content of $\mathrm{CP}$ and low content of NDF in HQH led to almost similar content of NFC among hays. However, the carbohydrate analysis revealed that contents of WSC, ethanol-soluble carbohydrates, and fructans in $\mathrm{HQH}$ were higher than in $\mathrm{MQH}$. The differ- 
Table 1. Composition of experimental diets and chemical composition of milk, hays, and starter concentrate (mean $\pm \mathrm{SD}$ )

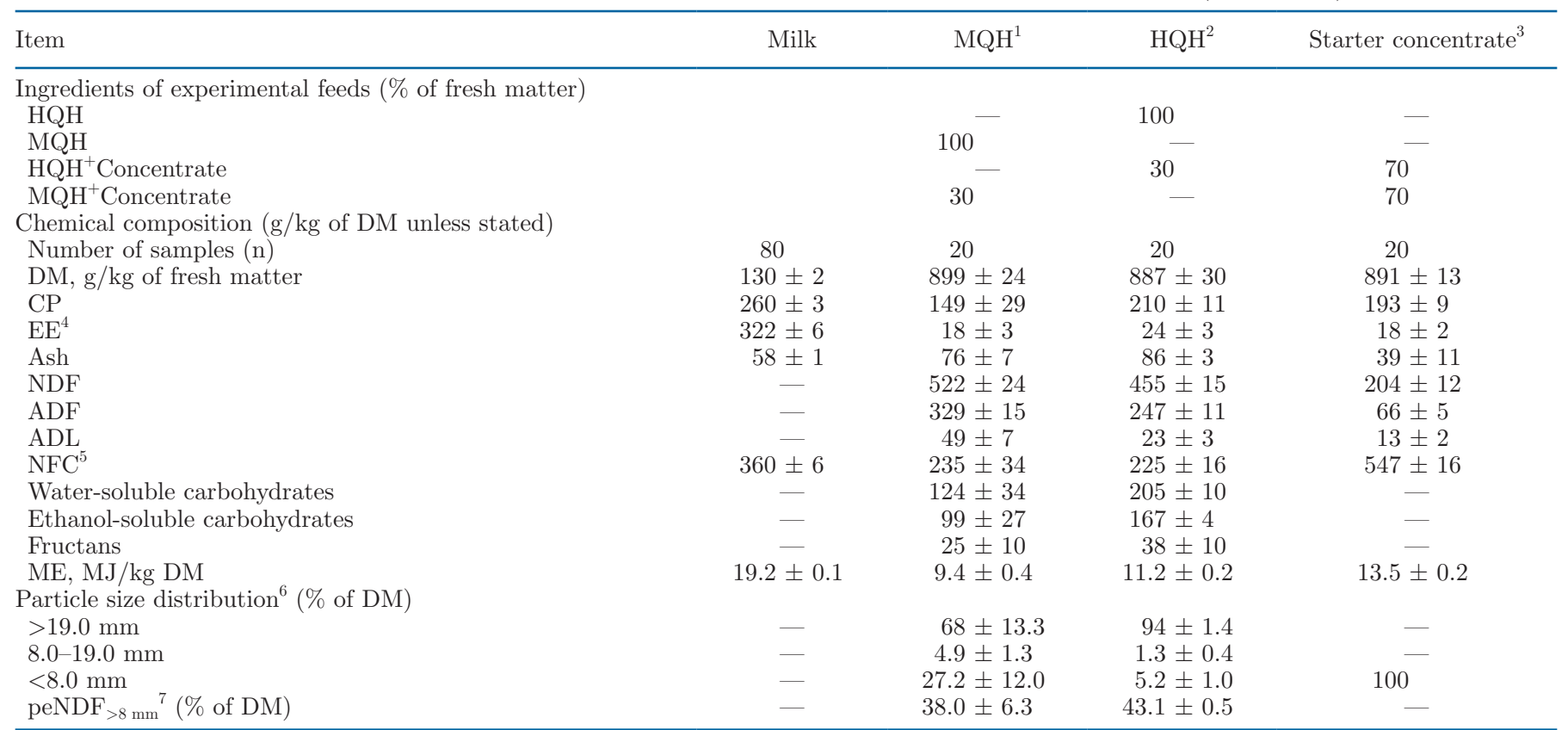

${ }^{1} \mathrm{MQH}=$ medium-quality hay.

${ }^{2} \mathrm{HQH}=$ high-quality hay.

${ }^{3}$ Starter concentrate consisted of $36 \%$ ground wheat, $35 \%$ ground barley, $17 \%$ soybean meal, $10 \%$ linseed meal, and $2 \%$ mineral premix [180 g of $\mathrm{Ca}, 40 \mathrm{~g}$ of P, $60 \mathrm{~g}$ of $\mathrm{Mg}, 80 \mathrm{~g}$ of $\mathrm{Na}, 1,500 \mathrm{mg}$ of $\mathrm{Cu}, 7,000 \mathrm{mg}$ of Zn, 4,000 $\mathrm{mg}$ of Mn, $40 \mathrm{mg}$ of Se, $60 \mathrm{mg}$ of Co, $160 \mathrm{mg}$ of I, 700,000 IU of vitamin $\mathrm{A}, 100,000 \mathrm{IU}$ of vitamin $\mathrm{D}_{3}$, and 2,500 IU of vitamin $\mathrm{E}$ (values per $\mathrm{kg}$ of feed)].

${ }^{4} \mathrm{EE}=$ ether extract.

${ }^{5} \mathrm{NFC}=1,000-\mathrm{Ash}-\mathrm{CP}-\mathrm{EE}-\mathrm{NDF}$; for milk, NFC consisted of lactose.

${ }^{6}$ Particle size distribution was determined with Penn State Particle Separator (Model C24682N, Nasco).

${ }^{7} \mathrm{peNDF}_{>8 \mathrm{~mm}}=$ physically effective NDF inclusive particles $>8 \mathrm{~mm}$, determined according to Kononoff et al. (2003) by multiplying the analyzed NDF content with the proportion of particles $>8 \mathrm{~mm}$.

ence between NFC and WSC was higher for MQH (111 $\mathrm{g} / \mathrm{kg}$ of DM) than for HQH (20 g/kg of DM), indicating a higher content of soluble fiber fractions (e.g., pectic substances) in MQH. The starter concentrate contained typical ingredients of starter feeds, resulting in higher $\mathrm{ME}$ and $\mathrm{CP}$ contents in both diets with concentrate.

\section{Milk, Water, and DM Intake}

Data of milk, water and DM intake are presented in Figure 1. Milk intake was slightly lower in the $\mathrm{MQH}$ group in the first $4 \mathrm{wk}$ and in $\mathrm{MQH}^{+} \mathrm{C}$ calves in the second week of life compared with the other feeding groups. From wk 5 on, milk intake did not differ between groups, as it was restricted by the milk feeding plan. Water intake was below $2.5 \mathrm{~L} / \mathrm{d}$ in all feeding groups in the first $7 \mathrm{wk}$ of life. From wk 8 to 11, calves fed HQH drank slightly more water, whereas water intake was lower in the MQH group compared with the other groups from wk 11 on. Water intake was 10.9, 13.9, 12.7, and $13.5 \mathrm{~L} / \mathrm{d}$ in $\mathrm{MQH}, \mathrm{HQH}, \mathrm{MQH}^{+} \mathrm{C}$, and $\mathrm{HQH}^{+} \mathrm{C}$ groups at the end of the experiment in wk 14 .
The DM intake from solid feeds was lower than $0.5 \mathrm{~kg} / \mathrm{d}$ until wk 8. In wk 1 to 4 , calves fed hay plus concentrate had higher DMI from solid feed than calves fed hay only, whereas no difference between diets was found in wk 5 to 8 (Supplemental Tables S1 and S2, https:/ /data.mendeley.com/datasets/s4nzf3h82c/1). Between wk 9 and 14, solid and total feed intake increased markedly. In this period, the average daily solid feed and total DM intake were lower in the groups fed only hay than in the groups with concentrate supplementation (Supplemental Table S3, https://data.mendeley.com/ datasets/s4nzf3h82c/1). Especially low DM intake was found for the MQH group in wk 13 and 14 of life (Figure 1).

\section{Nutrient Intake}

In wk 1 to 4 , calves fed hay and concentrate had higher CP, NFC, and ME intake from solid feed than MQH and HQH groups (Supplemental Table S1). In wk 5 to 8, provision of concentrate increased NFC and lowered ADF intake from solid feed (Supplemental Table 

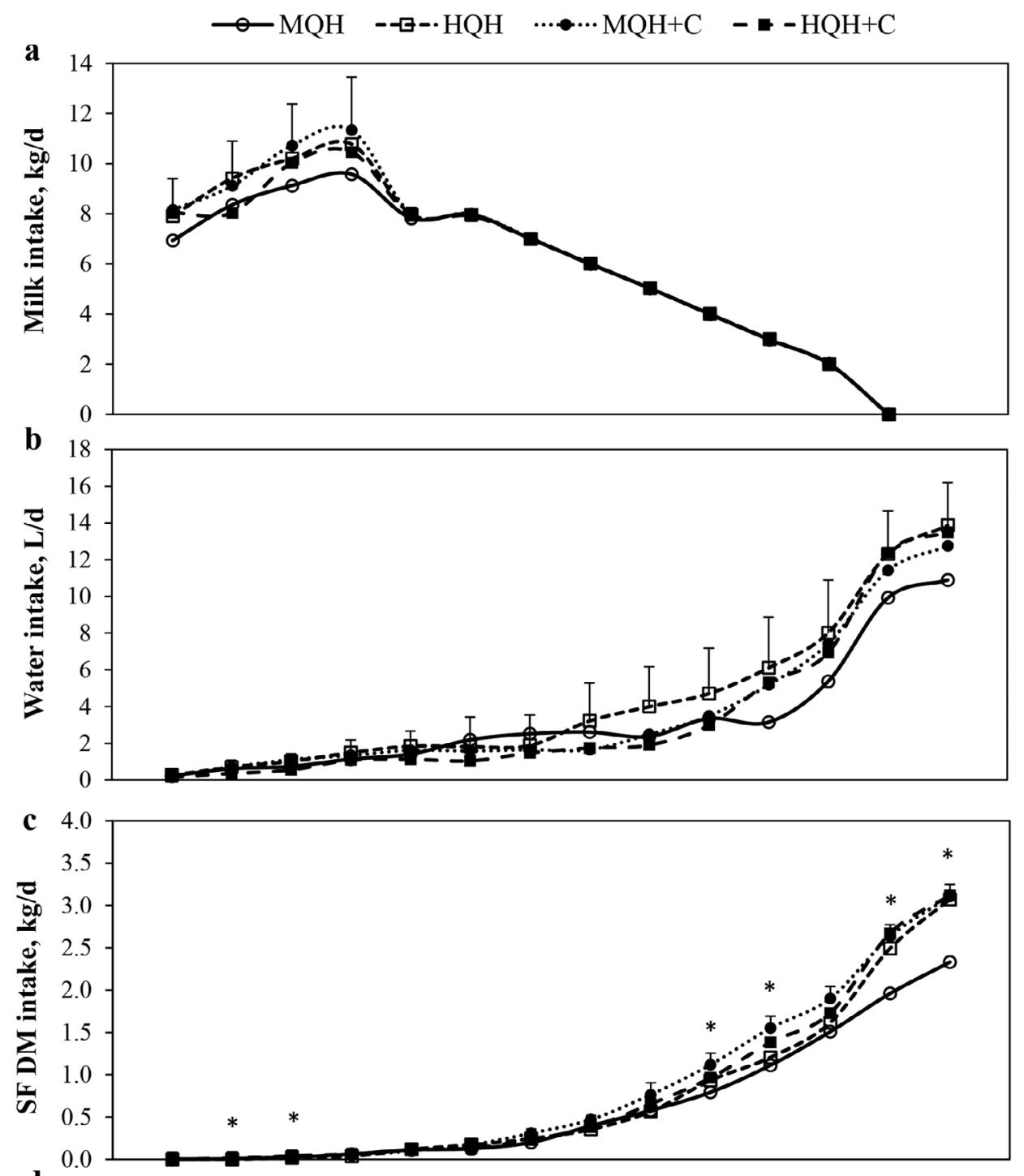

d

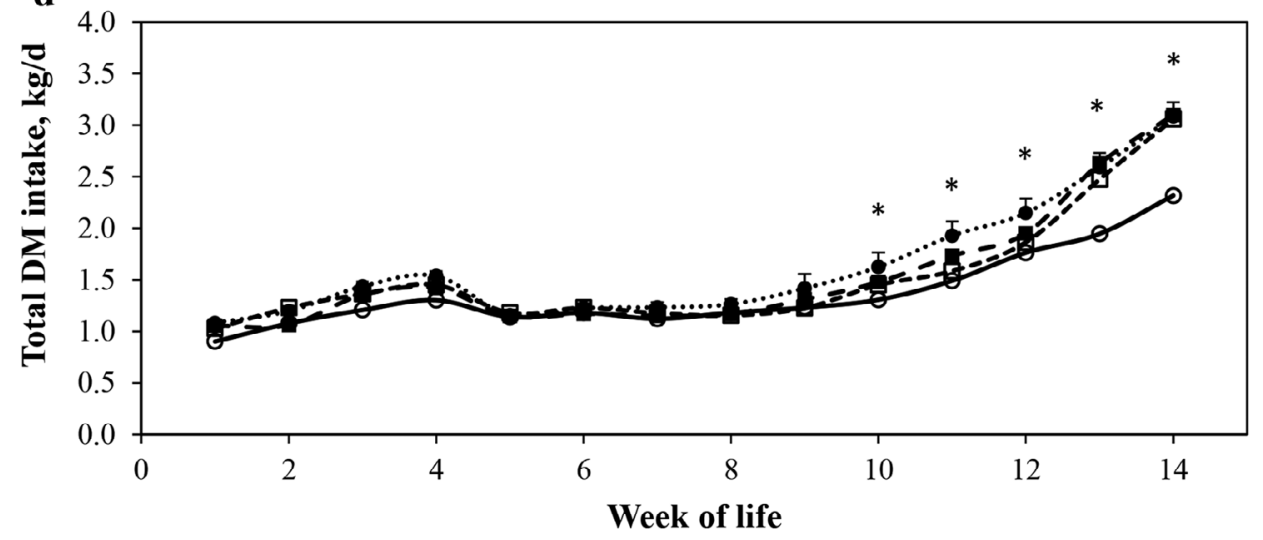

Figure 1. Variation in daily milk intake (a), water intake (b), solid feed (SF) DM intake (c), and total DM intake (d) of rearing calves fed hay of different qualities with or without supplementation of concentrates. $\mathrm{MQH}=100 \%$ medium-quality hay; HQH $=100 \%$ high-quality hay; $\mathrm{MQH}^{+} \mathrm{C}=30 \%$ medium-quality hay plus $70 \%$ concentrates; $\mathrm{HQH}^{+} \mathrm{C}=30 \%$ high-quality hay plus $70 \%$ concentrates. Asterisks indicate significant differences between diets in respective weeks. Significance was declared at $P<0.05$; error bars represent SEM. Values on solid feed DM intake in wk 1-14 and on total feed DM intake in wk 1-4 were square root-transformed [square root(x)], and values on total feed DM intake in wk 5-14 were $\log _{10}$-transformed $\left[\log _{10}(\mathrm{x})\right]$ before statistical analysis to reach normal distribution of data. The presented means were backtransformed. 

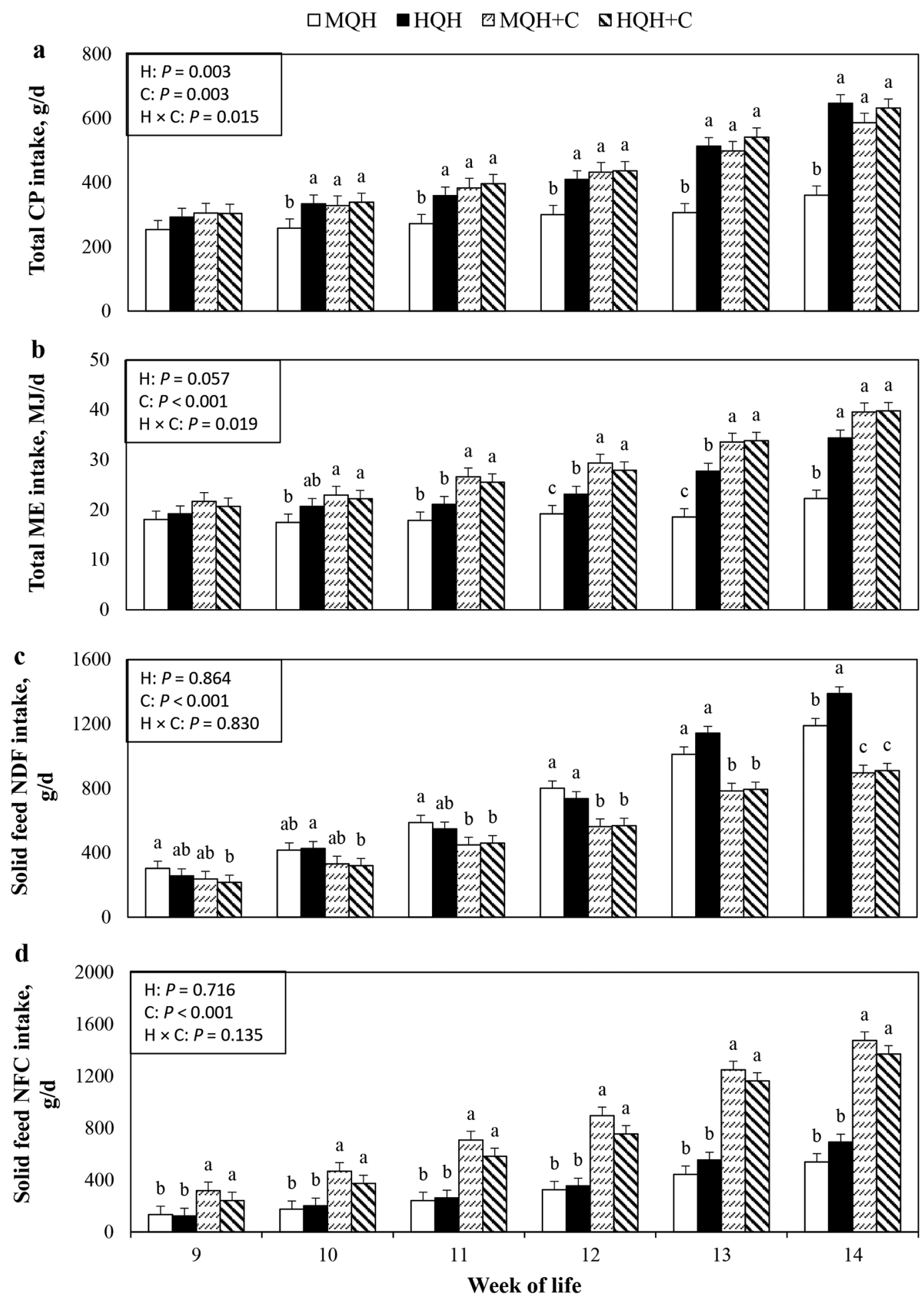

Figure 2. Overall effect of hay quality $(\mathrm{H})$, concentrate inclusion $(\mathrm{C})$, and their interaction $(\mathrm{H} \times \mathrm{C})$ on total $\mathrm{CP}$ intake $(\mathrm{a})$, total $\mathrm{ME}$ intake (b), solid feed NDF intake (c), and solid feed NFC intake (d) of rearing calves from wk 9 to 14 of life. MQH = 100\% medium-quality hay; HQH $=100 \%$ high-quality hay; $\mathrm{MQH}^{+} \mathrm{C}=30 \%$ medium-quality hay plus $70 \%$ concentrates; $\mathrm{HQH}^{+} \mathrm{C}=30 \%$ high-quality hay plus $70 \%$ concentrates Different letters $(\mathrm{a}-\mathrm{c})$ indicate differences among dietary treatments within each week. Significance was declared at $P<0.05$; error bars represent SEM. Values on total CP intake and total ME intake were $\log _{10}$-transformed $\left[\log _{10}(\mathrm{x})\right]$, and values on solid feed NDF and solid feed NFC intake were square root-transformed [square root(x)] before statistical analysis to reach normal distribution of data. The presented means were back-transformed. 

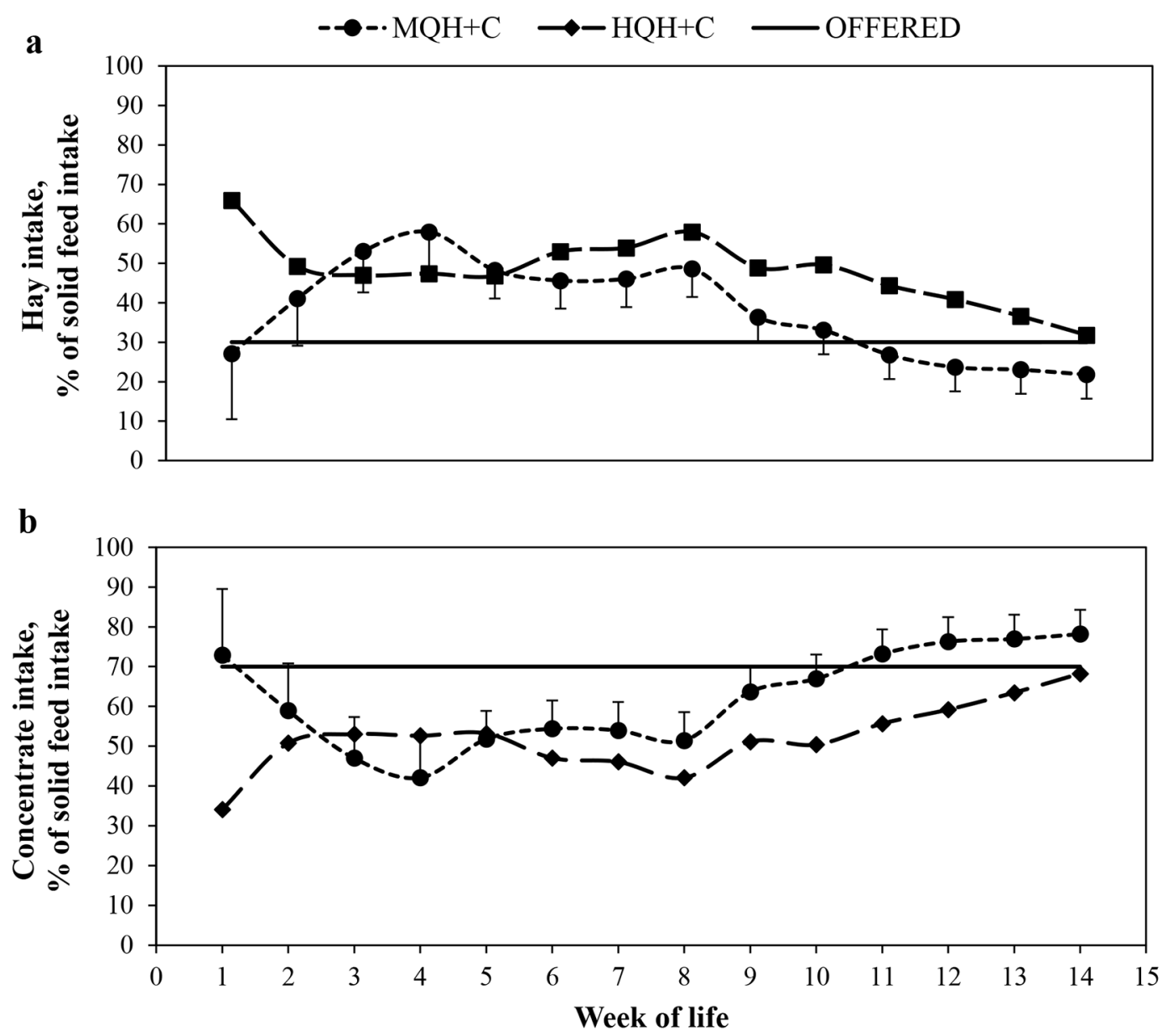

Figure 3. Proportion of hay (a) and concentrate intake (b) from solid feed intake of rearing calves fed hay of different qualities. $\mathrm{MQH}^{+} \mathrm{C}=$ $30 \%$ medium-quality hay plus $70 \%$ concentrates; $\mathrm{HQH}^{+} \mathrm{C}=30 \%$ high-quality hay plus $70 \%$ concentrates; OFFERED $=$ proportion of hay and concentrate in starter diet. Significance was declared at $P<0.05$; error bars represent SEM. Values on proportion of hay and concentrate intake in wk 9-14 were square root-transformed [square $\operatorname{root}(\mathrm{x})]$ before statistical analysis to reach normal distribution of data. The presented means were back-transformed.

S2). Furthermore, feeding HQH with or without concentrate resulted in lower ADL intake compared with groups fed MQH in the first 8 wk of life. Total DM, CP, and ME intakes were not affected by hay quality and concentrate inclusion in the first 8 wk of life, except for total CP intake in wk 5 to 8. In this period, calves fed $\mathrm{MQH}$ ingested less $\mathrm{CP}$ than those fed HQH. Although the ingested amounts were low in wk 1 to 8 , the nutrient intake from solid feed increased steadily in this period. In contrast, total $\mathrm{CP}$ and ME intake increased until wk 4 of life and decreased between wk 5 and 8 due to restricted milk supply from wk 5 on.

From wk 9 to 14 of life, a diet $\times$ week interaction was found for all analyzed traits of nutrient intake, except for total DMI (Figure 2 and Supplemental Table S3). In wk 9, total $\mathrm{CP}$ and $\mathrm{ME}$ intakes were comparable in all groups. However, from then on, CP intake remained rather constant in $\mathrm{MQH}$-fed calves and increased in the other groups. Furthermore, ME intake of the MQH group was lower than in the groups with concentrate supplementation in wk 10 to 14 . The ME intake of the calves offered $\mathrm{HQH}$ was intermediate, being significantly lower compared with the $\mathrm{MQH}^{+} \mathrm{C}$ and $\mathrm{HQH}^{+} \mathrm{C}$ groups in wk 11 to 13 , but higher compared with the MQH group in wk 12 to 14 . From wk 12 on, NDF intake from solid feed was lower in the groups with concentrate supplementation compared with those offered only hay. The NDF intake from solid feed did not differ between MQH and HQH groups, except for a higher NDF intake among calves fed HQH compared with the $\mathrm{MQH}$ group in wk 14. Furthermore, increased sorting against $\mathrm{MQH}$ hay in the $\mathrm{MQH}^{+} \mathrm{C}$ group compared with calves fed $\mathrm{HQH}^{+} \mathrm{C}$ compensated for higher NDF content in MQH, and resulted in similar NDF intake in the $\mathrm{MQH}^{+} \mathrm{C}$ and $\mathrm{HQH}^{+} \mathrm{C}$ groups. In wk 9 to 14 , concentrate intake made up $73.0 \%$ of solid feed intake in 
Week of life

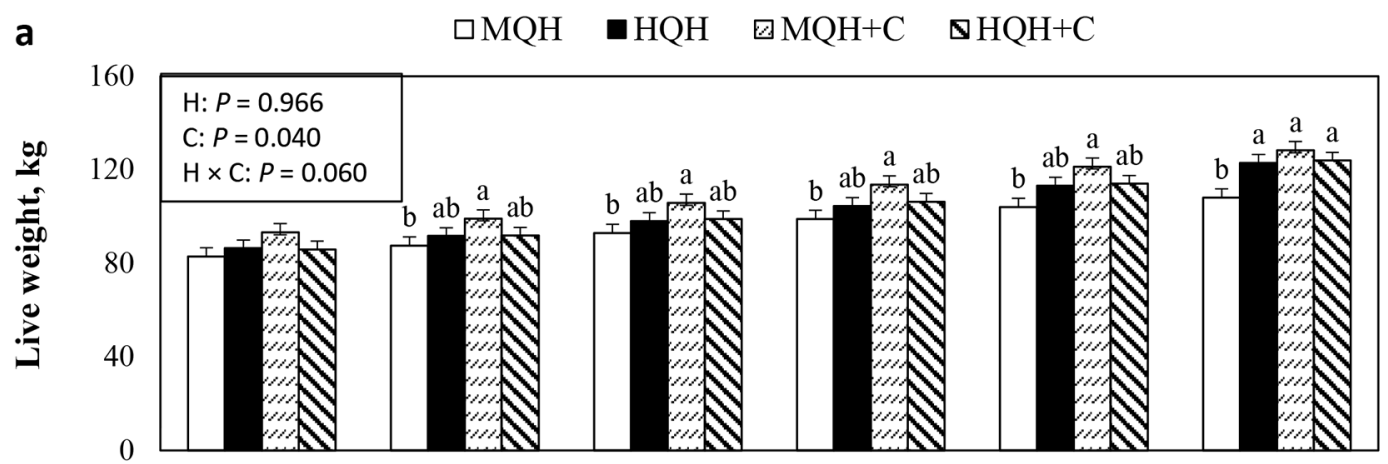

b

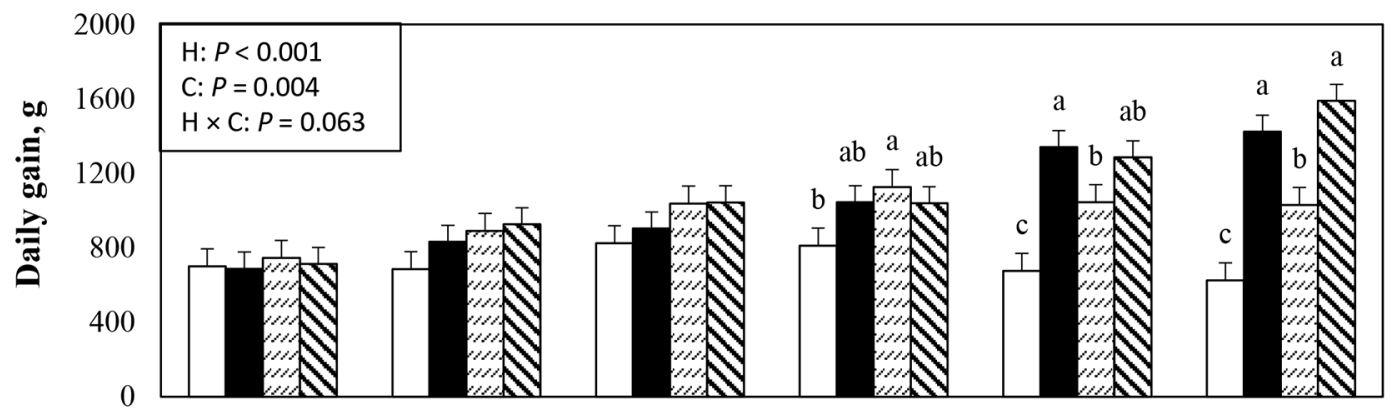

C

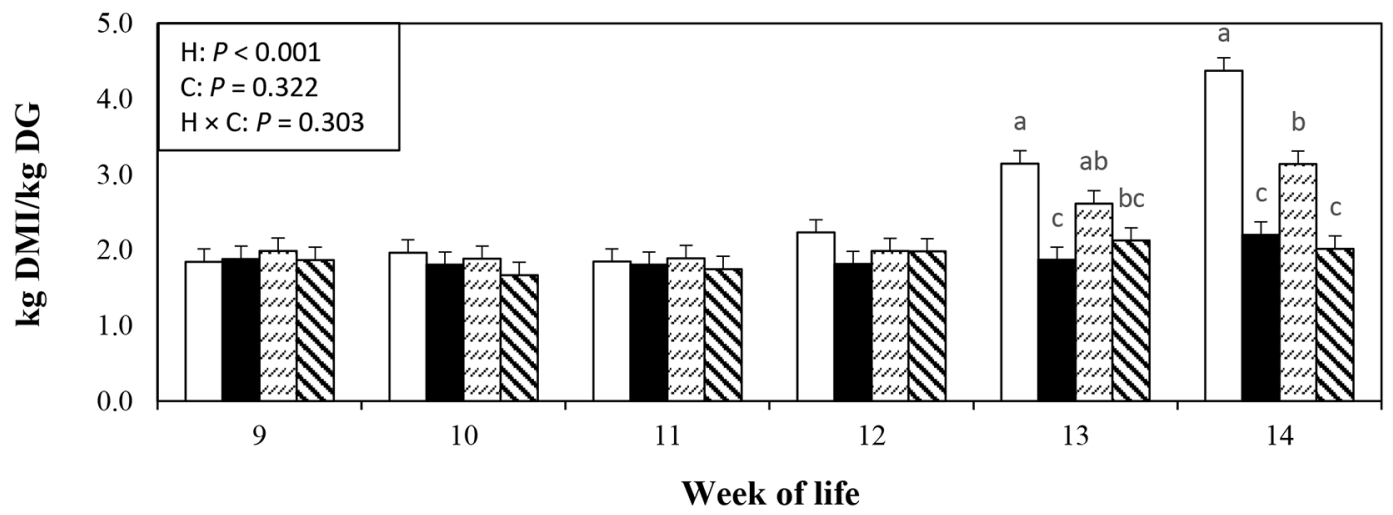

Figure 4. Overall effect of hay quality $(\mathrm{H})$, concentrate inclusion $(\mathrm{C})$, and their interaction $(\mathrm{H} \times \mathrm{C})$ on live weight (a), daily gain $(\mathrm{DG}$; b), and feed-to-gain ratio (c) of rearing calves from wk 9 to 14 of life. $\mathrm{MQH}=100 \%$ medium-quality hay; $\mathrm{HQH}=100 \%$ high-quality hay; $\mathrm{MQH} \mathrm{H}^{+} \mathrm{C}$ $=30 \%$ medium-quality hay plus $70 \%$ concentrates; $\mathrm{HQH}^{+} \mathrm{C}=30 \%$ high-quality hay plus $70 \%$ concentrates. Different letters (a-c) indicate differences among dietary treatments within each week. Significance was declared at $P<0.05$; error bars represent SEM. Values on feed-to-gain ratio were $\log _{10}$-transformed $\left[\log _{10}(\mathrm{x})\right]$ before statistical analysis to reach normal distribution of data. The presented means were back-transformed.

$\mathrm{MQH}^{+} \mathrm{C}$ calves compared with $58.6 \%$ in $\mathrm{HQH}^{+} \mathrm{C}$ calves $(P=0.082)$, whereby proportion of concentrate intake increased with age of calves in both groups (Figure 3, Supplemental Table S4, https://data.mendeley.com/ datasets/s4nzf3h82c/1). The NFC intake from solid feed was higher in groups with concentrate supplementation but did not differ between hay qualities.

\section{Live Weight, Daily BW Gain, and Feed-to-Gain Ratio}

Live weight, daily BW gain, and feed-to-gain ratio were not affected by hay quality and concentrate inclusion, and calves gained weight constantly in the first 8 wk of life (Supplemental Tables S1 and S2). However, similar to nutrient intake, a significant diet $\times$ week 
interaction was found for these variables during wk 9 to 14 of life (Figure 4). Calves of the $\mathrm{MQH}^{+} \mathrm{C}$ group were heavier than those of the $\mathrm{MQH}$ group from wk 10 on. In wk 14, calves of the $\mathrm{HQH}$ and $\mathrm{HQH}^{+} \mathrm{C}$ groups also had higher live weight compared with the $\mathrm{MQH}$ group. Furthermore, empty BW was also lower in calves fed $\mathrm{MQH}$ compared with other groups at the end of the experiment (Supplemental Table S5, https: //data.mendeley.com/datasets/s4nzf3h82c/1). Daily BW gain was not different between feeding groups until wk 11 of life. In wk 12 to 14 , calves of the $\mathrm{MQH}^{+} \mathrm{C}$ group gained significantly more BW than the animals of the MQH group. However, daily gains of calves fed $\mathrm{MQH}^{+} \mathrm{C}$ were lower compared with the $\mathrm{HQH}$ group in wk 13 and compared with $\mathrm{HQH}$ and $\mathrm{HQH}^{+} \mathrm{C}$ groups in wk 14. Empty BW gain was lower in the $\mathrm{MQH}$ group compared with all other groups and higher in calves fed $\mathrm{HQH}^{+} \mathrm{C}$ than in those fed HQH (Supplemental Table S5). In the weeks after weaning (wk 13 and 14), calves fed $\mathrm{MQH}$ or $\mathrm{MQH}^{+} \mathrm{C}$ consumed more $\mathrm{DM}$ per kilogram of daily BW gain than calves offered $\mathrm{HQH}$ or $\mathrm{HQH}^{+} \mathrm{C}$ (Figure 4, Supplemental Table S3).

\section{Apparent Total-Tract Nutrient Digestibility}

A significant hay quality $\times$ concentrate inclusion interaction was found for ATTD of all examined nutrients, except for NFC. The ATTD of OM and CP was significantly lower in the MQH-fed calves compared with the other feeding groups (Table 2). The OM digestibility of $\mathrm{HQH}$ was similar to the digestibility of the $\mathrm{MQH}^{+} \mathrm{C}$ and $\mathrm{HQH}^{+} \mathrm{C}$ rations. The ATTD of NDF and ADF of $\mathrm{HQH}$ averaged $83.2 \%$ and $78.2 \%$, respectively, both being significantly higher than ATTD of NDF and $\mathrm{ADF}$ in $\mathrm{MQH}$ and both hay-concentrate diets. Concen- trate inclusion significantly improved the NFC ATTD $(P<0.001)$, and ATTD of NFC tended to be higher in $\mathrm{HQH}$ than in MQH $(P=0.086)$.

\section{Blood Metabolites}

Results of blood metabolites are presented in Figures 5 and 6 . Glucose, insulin, lactate, and NEFA concentrations differed between feeding groups on $\mathrm{d} 1$. In the first week after birth, differences between diets were found in triglycerides (d 3 and 7) and cholesterol concentrations (d 7) in blood of calves. Throughout the rest of the experiment, concentrations of glucose, insulin, lactate, NEFA, triglycerides, and total protein in blood were not affected by diet. In contrast, BHB concentration was higher in blood of HQH-fed calves compared with other diets on d 77 (wk 11) of life. After weaning (d 91 or wk 13 of life), calves fed hay and concentrates had lower concentrations of both BHB and cholesterol in blood than calves offered hay only, independent of the hay quality.

\section{DISCUSSION}

Supporting early intake of solid feed-based energy and forage fiber is of enormous importance for young dairy calves' performance, rumen development, and health. Common starter concentrates are low in fiber, and young calves hardly eat fiber-rich ingredients during early life (Omidi-Mirzaei et al., 2018), jeopardizing their rumen development. Therefore, this research primarily aimed to establish and evaluate a feeding strategy for rearing calves based on a complete or partial replacement of starch-rich starter concentrates with hay of 2 different qualities. We evaluated whether this

Table 2. Apparent total-tract nutrient digestibility of the calves fed 4 different dietary treatments, measured in wk 14 of life

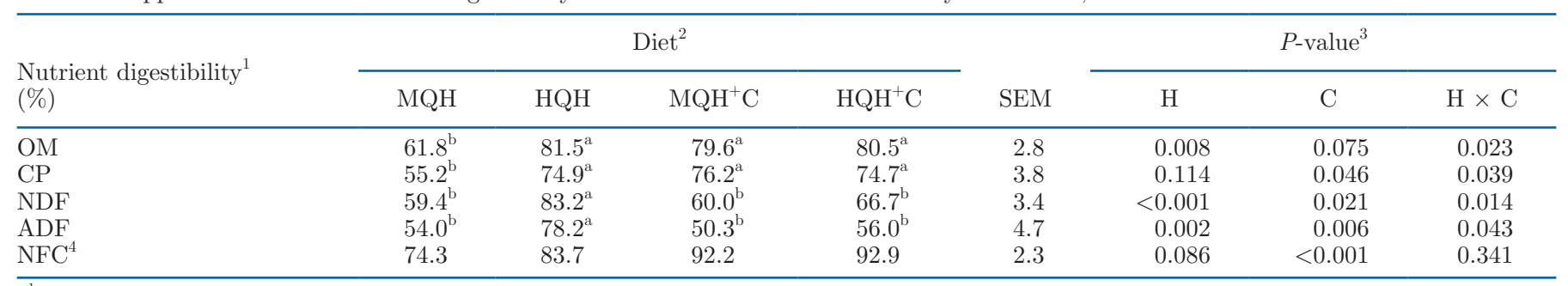

${ }_{\mathrm{a}, \mathrm{b}}$ Means bearing different superscripts differ at $P<0.05$.

${ }^{1}$ Apparent digestibility of rations was analyzed in experimental calves using the method by Kirchgessner et al. (2008). Average solid feed intake of calves during the digestibility experiment was 2.32, 3.06, 3.08, and 3.10 for $\mathrm{MQH}, \mathrm{HQH}, \mathrm{MQH}^{+} \mathrm{C}$, and $\mathrm{HQH}^{+} \mathrm{C}$ groups, respectively. $\mathrm{Nutrient}$ digestibility values were $\log _{10}$-transformed $\left[\log _{10}(\mathrm{x})\right]$ before statistical analysis to reach normal distribution of data. The presented means were back-transformed.

${ }^{2} \mathrm{MQH}=100 \%$ medium-quality hay; $\mathrm{HQH}=100 \%$ high-quality hay; $\mathrm{MQH}^{+} \mathrm{C}=30 \%$ medium-quality hay plus $70 \%$ concentrates; $\mathrm{HQH}^{+} \mathrm{C}=$ $30 \%$ high-quality hay plus $70 \%$ concentrates.

${ }^{3}$ The effect of hay quality $(\mathrm{H})$, concentrate inclusion $(\mathrm{C})$, and their two-way interaction $(\mathrm{H} \times \mathrm{C})$. The effects of sex and $\mathrm{H} \times \mathrm{C} \times$ sex interaction were not significant in any analyzed trait.

${ }^{4} \mathrm{NFC}=1,000-\mathrm{Ash}-\mathrm{CP}-$ ether extract $-\mathrm{NDF}$. 
$\square \mathrm{MQH} \quad \mathbf{H Q H} \quad \square \mathrm{MQH}+\mathrm{C} \quad \mathbf{\mathbf { H Q H }}+\mathrm{C}$
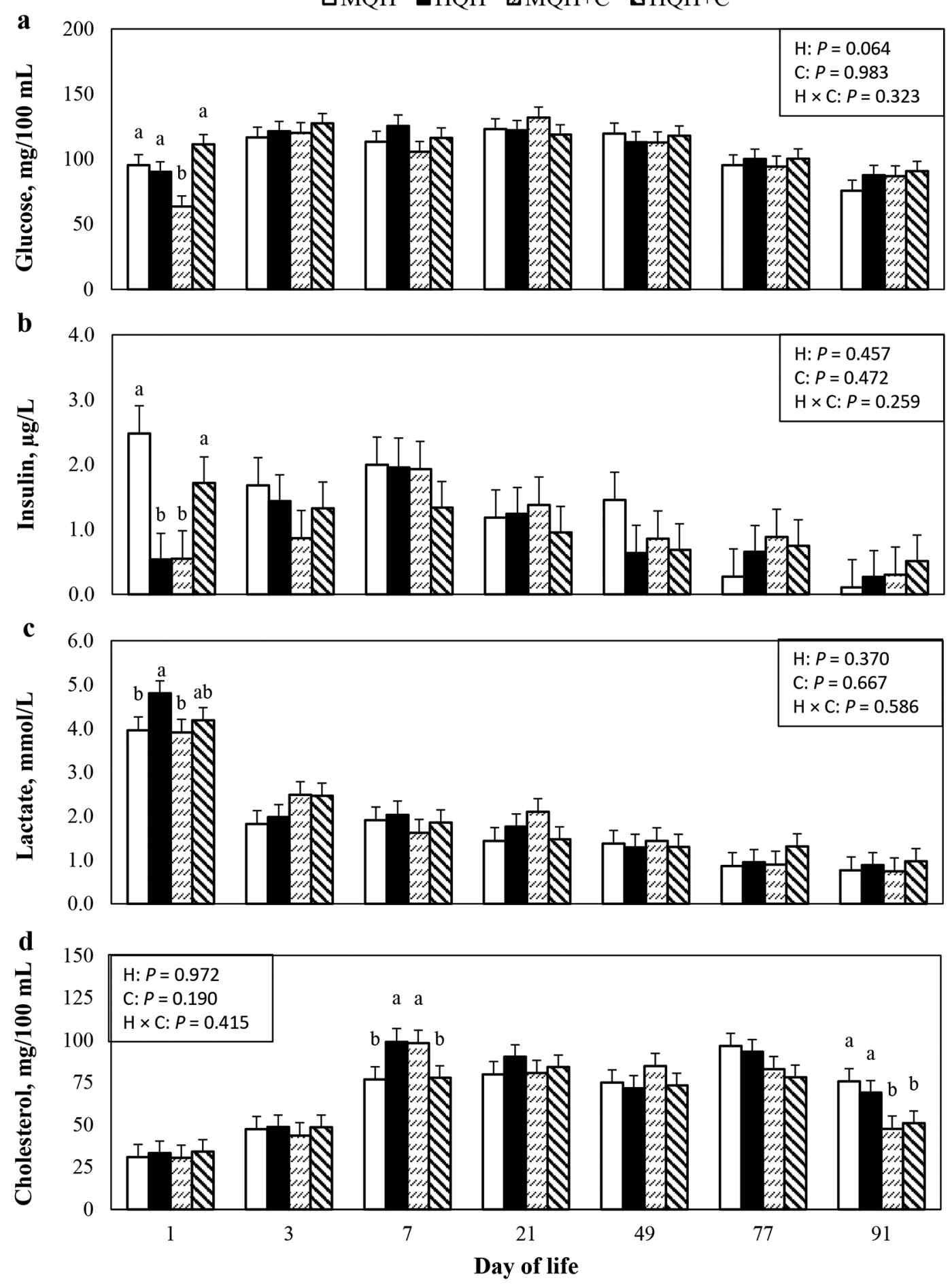

Figure 5. Overall effect of hay quality $(\mathrm{H})$, concentrate inclusion $(\mathrm{C})$, and their interaction $(\mathrm{H} \times \mathrm{C})$ on glucose (a), insulin (b), lactate (c), and cholesterol concentration (d) in blood of rearing calves. $\mathrm{MQH}=100 \%$ medium-quality hay; $\mathrm{HQH}=100 \%$ high-quality hay; $\mathrm{MQH}{ }^{+} \mathrm{C}=30 \%$ medium-quality hay plus $70 \%$ concentrates; $\mathrm{HQH}^{+} \mathrm{C}=30 \%$ high-quality hay plus $70 \%$ concentrates. Different letters (a, b) indicate differences among dietary treatments within each week. Significance was declared at $P<0.05$; error bars represent SEM. 

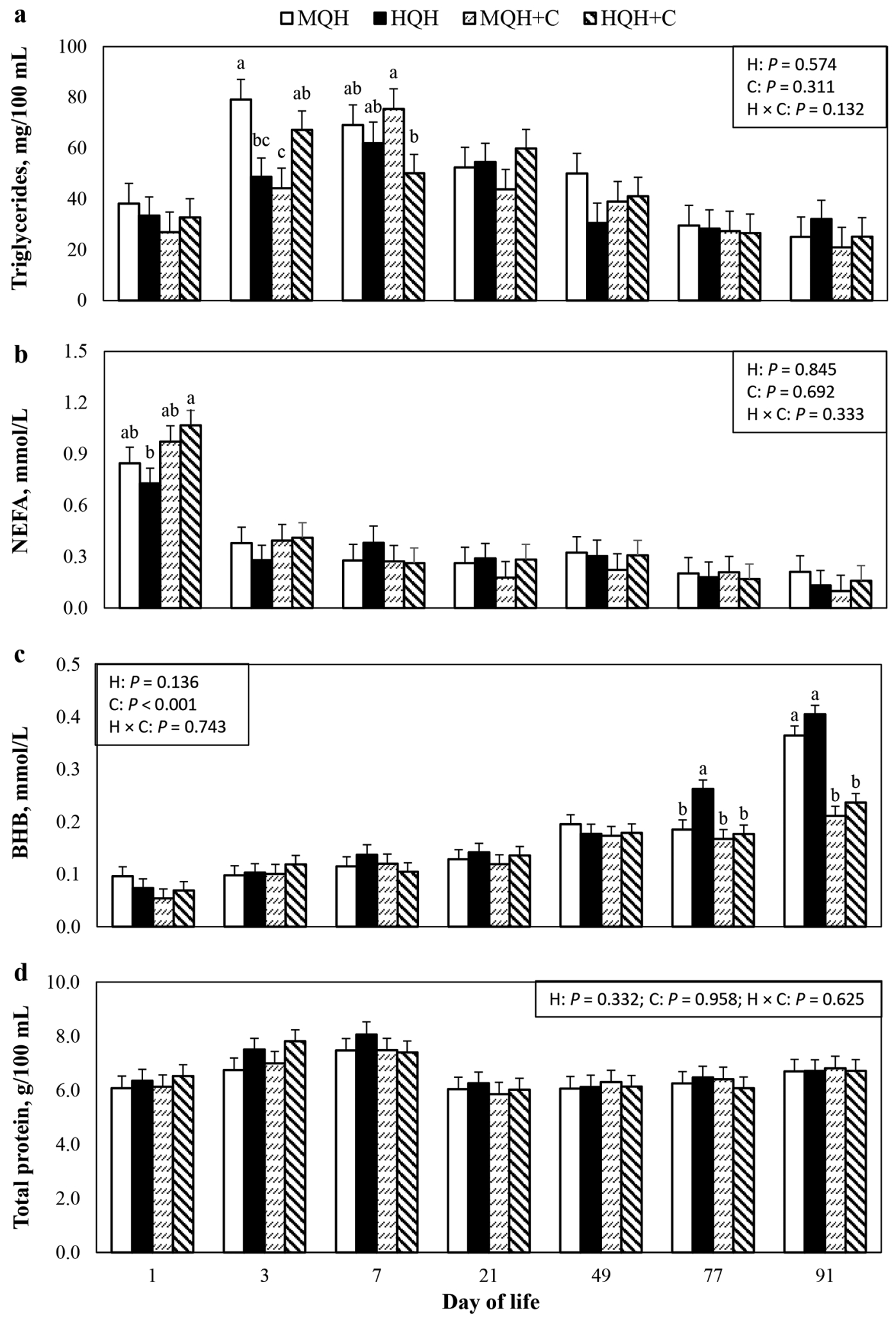

Figure 6. Overall effect of hay quality $(\mathrm{H})$, concentrate inclusion $(\mathrm{C})$, and their interaction $(\mathrm{H} \times \mathrm{C})$ on concentration of triglycerides $(\mathrm{a})$, nonesterified fatty acids (NEFA; b), BHB (c), and total protein (d) in blood of rearing calves. $\mathrm{MQH}=100 \%$ medium-quality hay; $\mathrm{HQH}=100 \%$ high-quality hay; $\mathrm{MQH}^{+} \mathrm{C}=30 \%$ medium-quality hay plus $70 \%$ concentrates; $\mathrm{HQH}^{+} \mathrm{C}=30 \%$ high-quality hay plus $70 \%$ concentrates. Different letters $(\mathrm{a}-\mathrm{c})$ indicate differences among dietary treatments within each week. Significance was declared at $P<0.05$; error bars represent SEM. 
solid feeding helps maintain high feed and nutrient intake, growth performance, and metabolic health while enabling high NDF intake and digestibility in rearing dairy calves from birth to shortly after weaning. We hypothesized that feeding hay rich in WSC and CP can fully replace concentrate-rich starter feeds in dairy rearing calves without adverse effects on feed and nutrient intake, daily gain performance, and metabolism. This hypothesis was based on newly reported knowledge of our team (Kleefisch et al., 2017; Klevenhusen et al., 2017) and others (Moorby et al., 2006) in which such hay almost fully replaced concentrates in the feeding of dairy cows during early lactation.

Indeed, the most significant findings of our research were high total DM, CP, and ME intake as well as high daily gains of calves fed HQH after weaning, which were on a comparable level with those of calves fed concentrate-based starters. In contrast, feeding MQH without supplementation of concentrate led to markedly lower DM, CP, and ME intake as well as lower daily gains and higher feed-to-gain ratio. This finding is important because it shows that forage quality plays an essential role in supplying the young rearing calves with $\mathrm{ME}$ and $\mathrm{CP}$, likely even more than the proportion of concentrates in the starter diet, which, as shown in this study, increased with the calf's age. The increased DM and ME intake of calves fed HQH compared with those offered MQH can be explained by the higher ATTD of nutrients. In particular, ATTD of NDF and ADF was significantly higher in the $\mathrm{HQH}$ diet compared with the other diets.

Because fiber is mainly digested in the rumen, this indicates a higher NDF degradability of $\mathrm{HQH}$ in the rumen of weaned calves. Higher NDF degradability in the rumen of the young calves yields greater amounts of short-chain fatty acids, especially acetate (our unpublished data), increases the amount of ME available for calves, and stimulates feed intake by enhancing ruminal turnover of ingested feed (Mertens, 1994; Gruber et al., 2005). Khan et al. (2020) fed calves with either a concentrate starter or a forage starter (chopped alfalfabased silage) until wk 8 of life. The nutritive value of the forage starter $(60.4 \%$ apparent OM digestibility, 9.7 $\mathrm{MJ}$ of $\mathrm{ME} / \mathrm{kg}$ of $\mathrm{DM}$ ) was comparable to that of $\mathrm{MQH}$ in our study, but apparent OM digestibility was approximately $20 \%$ lower, and ME content was approximately $1.5 \mathrm{MJ} / \mathrm{kg}$ of $\mathrm{DM}$ lower than in $\mathrm{HQH}$ in our study. Khan et al. (2020) found that total short-chain fatty acid concentration of rumen fluid was $42.4 \%$ lower in calves fed forage starter compared with concentrate starter-fed calves at $7 \mathrm{wk}$ of life. Thus, outcomes of the study by Khan et al. (2020) and our experiments indicate that medium-quality forage limits ruminal fermentation when fed as the only solid feed source, but this is not the case for HQH, due to increased NDF and ADF digestibility.

Independent of the diets fed, solid feed intake was below $0.50 \mathrm{~kg}$ of $\mathrm{DM} / \mathrm{d}$ until the end of wk 8 , at which point calves still received $6.0 \mathrm{~kg}$ of acidified whole milk per day as part of the daily ration. Only further reduction of milk supply after $8 \mathrm{wk}$ resulted in an appreciable increase of solid feed intake. Indeed, models developed by Silva et al. (2019) suggested that milk intake and age are the main factors affecting solid feed intake in calves. At an age of around 8 to $9 \mathrm{wk}$, they estimated a $0.93-\mathrm{g}$ decrease in daily solid feed intake per $100 \mathrm{~g}$ of DMI from milk. In addition to milk intake preweaning, characteristics (e.g., type of carbohydrate, physical form of starter feed) and digestibility of the starter feed may affect DM and energy intake of calves (Quigley, 2019). Furthermore, Quigley et al. (2019) found that nutrient digestibility of the starter feed increased with cumulative NFC intake from starter feeds in calves. These findings likely explain the markedly lower solid feed intake of calves in the current experiment compared with earlier studies with lower milk intake of calves, especially in the second month of life (Castells et al., 2012; Terré et al., 2013). However, in wk 14 of life, daily DM intake of the $\mathrm{HQH}, \mathrm{HQH}^{+} \mathrm{C}$, and $\mathrm{MQH}^{+} \mathrm{C}$ groups were on a similar level to that found in the study by Aragona et al. (2020), in which calves were weaned before d 58 of life and fed a concentrate starter supplemented with $5 \%$ chopped hay after weaning.

Interestingly, our results regarding the enhancing effect of feeding high-quality hay on feed intake of calves are similar to the outcome of a study with dairy cows (Kleefisch et al., 2017), indicating that young rearing calves can utilize HQH with the same efficiency as adult dairy cattle. In their study, Kleefisch et al. (2017) fed either $100 \% \mathrm{HQH}, 75 \% \mathrm{HQH}$ plus $25 \%$ concentrates, or $60 \% \mathrm{HQH}$ plus $40 \%$ concentrates, and found no differences between diets regarding apparent $\mathrm{OM}$ and $\mathrm{CP}$ digestibility. As in the current experiment, apparent NDF and ADF digestibility were higher in the $100 \% \mathrm{HQH}$ diet compared with the hay-concentrate mixtures, and the opposite was found for apparent NFC digestibility (Kleefisch et al., 2017). Because the NFC of HQH is primarily made of WSC, these results indicate a relatively lower digestibility of hay oligosaccharides and fructans in both young and adult cattle for $\mathrm{HQH}$ compared with starch found in the concentrate. Taking into account the high level of WSC in the HQH (20.5\%), a low degradability of sugars might be desirable in terms of maintaining rumen health, which was observed in dairy cows (Klevenhusen et al., 2019). As reported in a companion paper, we observed that ruminal $\mathrm{pH}$ was higher in calves fed $\mathrm{MQH}$ than in groups containing either $\mathrm{HQH}$ and concentrate-based starters, but the $\mathrm{pH}$ 
was always above 6.0 (Poier et al., 2020), which can be considered normal for a healthy rumen. Furthermore, a higher ammonia concentration in calves fed $\mathrm{HQH}$ could be expected, as those ingested similar amounts of CP but less ME compared with calves fed concentratebased starters. However, results of a companion paper (our unpublished data) show that diet did not significantly affect ruminal ammonia concentration of calves in the second and third month of life. An analysis of ruminal degradability of diets could be beneficial to obtain more information on the protein and energy supplies of ruminal microbes.

In our experiment, the effect of forage quality was much less pronounced if forage-concentrate mixtures were used as starter diet. The $\mathrm{CP}$ and ME intakes were not different between $\mathrm{MQH}^{+} \mathrm{C}$ and $\mathrm{HQH}^{+} \mathrm{C}$ groups at any time during the experiment, although DM intake was on a similar level and nutrient content of MQH was lower compared with $\mathrm{HQH}$. The absence of differences in $\mathrm{CP}$ and $\mathrm{ME}$ intake between groups with concentrate supplementation was due to more distinctive concentrate sorting in calves fed the $\mathrm{MQH}^{+} \mathrm{C}$ diet. According to Miller-Cushon and DeVries (2015, 2017), feed sorting can be learned by calves, but is also regulated by feedback mechanisms. Accordingly, calves with limited energy supply select for concentrate, but calves suffering from low ruminal $\mathrm{pH}$ select for fiber-rich feeds. It is explainable that calves fed $\mathrm{MQH}^{+} \mathrm{C}$ showed higher sorting for concentrates, as $\mathrm{MQH}$ had lower $\mathrm{CP}$ and $\mathrm{ME}$ content than HQH. However, as shown in a companion paper, there was no difference in the ruminal $\mathrm{pH}$ in calves fed $\mathrm{HQH}^{+} \mathrm{C}$ or $\mathrm{MQH}^{+} \mathrm{C}$ (Poier et al., 2020), indicating that greater sorting for hay in the $\mathrm{HQH}^{+} \mathrm{C}$ group and greater sorting for concentrate in the $\mathrm{MQH}^{+} \mathrm{C}$ group was driven by the differing energy concentrations of the hays as well as their palatability, and not by ruminal $\mathrm{pH}$. Indeed, research from Miller-Cushon et al. (2014) and Miller-Cushon and DeVries (2015) found that sensory properties and palatability of feed play an important role regarding feed sorting behavior of calves. The HQH was based on English ryegrass, early cut and dried indoors, resulting in a high proportion of leaves and low proportion of stems. In addition to the higher content of WSC, the $\mathrm{HQH}$ was still green and aromatic, likely contributing to the overall palatability, as seen in the sorting behavior of the calves in favor of hay.

Although experimental feeds differed markedly in chemical composition, concentrations of glucose, insulin, lactate, triglycerides, and NEFA did not differ between experimental groups, except for the first week. These differences may not be related to different feeding strategies, as solid feed intake was very low in the first week of life. The different concentrations of these metabolites in blood can only be explained by different intakes of milk during the first week, which, again, was independent of the solid feed intake. In contrast, feeding the hay-based starter led to higher BHB and cholesterol concentrations in blood of calves compared with the groups with concentrate supplementation. The difference of higher serum BHB was already evident before weaning in calves fed the HQH (wk 11), whereas after weaning both BHB and cholesterol were higher in the hay-fed calves independent of the hay quality. The study by Khan et al. (2020) found higher BHB concentrations but also lower NEFA concentrations at weaning in calves fed only forage compared with those fed only concentrates. High NEFA and BHB levels in blood are often related to energy mobilization as a consequence of acute glucose shortage in blood. The NEFA are generated by lipolysis, and subsequently they are transported to the liver to generate energy by oxidation or are converted into ketone bodies, such as BHB, when glucose (oxaloacetate) is missing (Drackley, 1999). However, glucose concentration in blood was within reference levels for calves in all experimental groups (Mohri et al., 2007), and concentrations of NEFA and triglycerides did not differ between feeding groups in the present study. Besides conversion from NEFA in the liver, $\mathrm{BHB}$ are also generated in the rumen epithelium via ruminally produced butyrate (Bergman, 1990). About $90 \%$ of ruminal butyrate is metabolized in the rumen epithelium, being converted mainly to BHB (Bergman, 1990) via 3-methylglutaryl CoA (HMG-CoA; Baldwin, 1998), leading to high BHB concentration in blood, which is used as an energy source by the peripheral tissues (Sutton et al., 1963). Research by Kleefisch et al. (2017) showed an increased butyrate proportion in the rumen of dairy cows fed HQH compared with animals receiving diets that contain both hay and concentrates. It is known that the ruminal degradation of WSC results in increased butyrate and acetate in the rumen (Klevenhusen and Zebeli, 2021), and this may explain the already increased ruminal ketogenesis before weaning in calves fed the $\mathrm{HQH}$ starter diet.

Butyrate is the preferred substrate for rumen epithelial metabolism, and a high butyrate concentration in the rumen promotes not only ketogenesis but also the development of the rumen epithelium, leading to a higher metabolic capacity (Sander et al., 1959; Sutton et al., 1963). Thus, the choice of solid feeds in calf rearing may also affect development of rumen morphology and metabolism. In other research, feeding forages as supplementation to concentrates resulted in higher rumen and reticulorumen weights (Baldwin et al., 2004; Khan et al., 2011), as well as higher ruminal pH (Khan et al., 2011; Castells et al., 2013; Terré et al., 2013), lower incidence of poorly developed rumen mu- 
cosa (Suárez et al., 2007), and lower risk of subclinical ruminal acidosis (Laarman and Oba, 2011). However, information is lacking on whether and to what extent hay quality affects development of the gastrointestinal tract in young calves, especially at the histological and molecular levels, which warrants further research.

In this experiment, serum cholesterol increased from roughly 30 to $50 \mathrm{mg} / 100 \mathrm{~mL}$ on d 1 and 3 to about 80 $\mathrm{mg} / 100 \mathrm{~mL}$ on $\mathrm{d} 7$ of life, and maintained this level until d 77 (wk 11), which is within the reference levels reported for young calves (Yu et al., 2019). However, after weaning, the cholesterol concentration decreased in both groups fed the concentrate-based starter feed but not in the hay-fed calves. Cholesterol is an important constituent of cellular membranes and hormones, so that its concentration is tightly regulated by both its biosynthesis and also the efflux. Biosynthesis is modulated mainly by the need for new cholesterol and is orchestrated by an array of regulatory pathways (Dempsey, 1974), which are affected by the presence of precursor substances (Bionaz et al., 2020). Because the calves in our study were all growing and healthy, we assume that the need for new cholesterol should have been the same, but the levels of precursors coming from the rumen might have been different, especially the levels and profiles of short-chain fatty acids affecting the availability of HMG-CoA, which, in addition to ruminal ketogenesis, may also be used for cholesterol biosynthesis (Steele et al., 2011). In ruminants, acetate and glucose are believed to be the key precursors for cholesterol biosynthesis occurring mainly in adipose tissue and small intestine (Liepa et al., 1978; Bionaz et al., 2020), but recent indications of increased cholesterogenesis in the rumen of adult bovines fed a forage-rich diet also exist (Steele et al., 2011). The onset of rumen and hindgut fermentation starting from d 7 (our unpublished data) likely stimulated biosynthesis of cholesterol in all calves, whereas the higher cholesterol concentration maintained in calves fed only hay can be explained by higher NDF intake and ruminal acetate production observed in these calves (our unpublished data). It is possible that feeding of concentrates downregulated the biosynthesis of cholesterol in weaned calves in the same way as observed in adult cattle via decreased ruminal cholesterogenesis. Accordingly, Steele et al. (2011) found downregulation of the genes responsible for cholesterol biosynthesis in the rumen epithelium of dry cows fed $65 \%$ grain in the diet, and this effect was modulated not only by changes in the diet but also by the drop of $\mathrm{pH}$, acidosis, and inflammation, which increase the removal of cholesterol from blood. Calves in our study did not show signs of ruminal acidosis and inflammation, despite feeding $70 \%$ grain (our unpublished data). Therefore, the concentration of serum cholesterol can only be affected by its biosynthesis, which obviously was stimulated in the rumen by feeding the hay diets, whereas concentrate feeding depressed it. Further long-term research is needed to establish the role of increased cholesterogenesis in the health and development of calves fed hay-rich diets.

\section{CONCLUSIONS}

Overall, this research showed that high-quality hay as the only solid feed can substitute concentrate-rich starter feeds in dairy calves without adverse effects on calves' feed intake and growth performance, especially during the highly sensitive phase of weaning. In contrast, feeding medium-quality hay led to lower feed intake and lower daily gain. The high apparent digestibility of nutrients and the high $\mathrm{CP}$ content enabled calves fed high-quality hay to ingest daily amounts of $\mathrm{CP}$ and ME similar to those of calves provided concentrate-rich starter feeds, while stimulating the intake of WSC and NDF. This was associated with an increase in serum $\mathrm{BHB}$ concentration even before weaning, and both BHB and cholesterol concentration after weaning, suggesting higher metabolic capacity of the rumen epithelium with an improved ruminal ketogenesis and cholesterogenesis in calves around weaning. Further research is needed to evaluate the long-term consequences of feeding high-quality hay on the health and development of dairy calves, especially in terms of the observed improvements in ruminal ketogenesis and cholesterogenesis around weaning.

\section{ACKNOWLEDGMENTS}

The authors are very grateful to K. Neuhofer (ARGE Heumilch Austria) for kindly providing the high-quality hay. Furthermore, we thank J. Häusler, D. Eingang, A. Schauer, P. Unterweger and J. Kaufmann (Agricultural Research and Education Centre Raumberg-Gumpenstein, Irdning-Donnersbachtal, Austria) for production of medium-quality hay, conducting the feeding trial, and analyzing feed and feces, as well as A. Dockner (University of Veterinary Medicine Vienna) for conducting the blood analyses. This research was funded by the Austrian Federal Ministry of Agriculture, Regions and Tourism (grant number: BMLRT 101369; Vienna). Fenja Klevenhusen, Georg Terler, and Qendrim Zebeli acquired funding and planned and designed the study. Gregor Poier and Georg Terler were responsible for coordination and execution of feeding trial and analyses, data curation, and statistical analyses. Qendrim Zebeli supervised the feeding trial and the data analyses. Georg Terler, Gregor Poier, and Qendrim Zebeli wrote the first draft. Fenja Klevenhusen was responsible for 
revision and editing of the manuscript. The authors have not stated any conflicts of interest.

\section{REFERENCES}

Aragona, K. M., F. X. Suarez-Mena, T. S. Dennis, J. D. Quigley, W. Hu, T. M. Hill, and R. L. Schlotterbeck. 2020. Effect of starter form, starch concentration, and amount of forage fed on Holstein calf growth from 2 to 4 months of age. J. Dairy Sci. 103:2324-2332. https://doi.org/10.3168/jds.2019-17474.

Baldwin, R. L., K. R. McLeod, J. L. Klotz, and R. N. Heitmann. 2004. Rumen development, intestinal growth and hepatic metabolism in the pre- and postweaning ruminant. J. Dairy Sci. 87:E55-E65. https://doi.org/10.3168/jds.S0022-0302(04)70061-2.

Baldwin, R. L. VI 1998. Use of isolated ruminal epithelial cells in the study of rumen metabolism. J. Nutr. 128:293S-296S. https://doi .org/10.1093/jn/128.2.293S.

Bergman, E. N. 1990. Energy contributions of volatile fatty acids from the gastrointestinal tract in various species. Physiol. Rev. 70:567590. https://doi.org/10.1152/physrev.1990.70.2.567.

Bionaz, M., E. Vargas-Bello-Pérez, and S. Busato. 2020. Advances in fatty acids nutrition in dairy cows: from gut to cells and effects on performance. J. Anim. Sci. Biotechnol. 11:110. https://doi.org/10 .1186/s40104-020-00512-8.

Castells, L., A. Bach, G. Araujo, C. Montoro, and M. Terré. 2012. Effect of different forage sources on performance and feeding behavior of Holstein calves. J. Dairy Sci. 95:286-293. https://doi.org/10 $.3168 / \mathrm{jds} .2011-4405$.

Castells, L., A. Bach, A. Aris, and M. Terré. 2013. Effects of forage provision to young calves on rumen fermentation and development of the gastrointestinal tract. J. Dairy Sci. 96:5226-5236. https:// doi.org/10.3168/jds.2012-6419.

Dempsey, M. E. 1974. Regulation of steroid biosynthesis. Annu. Rev. Biochem. 43:967-990. https://doi.org/10.1146/annurev.bi.43 .070174 .004535 .

DLG (Deutsche Landwirtschafts-Gesellschaft). 1997. DLG-Futterwerttabellen - Wiederkäuer [DLG feed value tables - Ruminants]. Vol. 7. DLG-Verlag.

Drackley, J. K. 1999. Biology of dairy cows during the transition period: The final frontier? J. Dairy Sci. 82:2259-2273. https://doi .org/10.3168/jds.S0022-0302(99)75474-3.

Engelking, L. E., T. Matsuba, K. Inouchi, T. Sugino, and M. Oba. 2020. Effects of feeding hay and calf starter as a mixture or as separate components to Holstein calves on intake, growth, and blood metabolite and hormone concentrations. J. Dairy Sci. 103:44234434. https://doi.org/10.3168/jds.2019-17676.

Fricke, P. M. 2004. Strategies for optimizing reproductive management of dairy heifers. Adv. Dairy Technol. 16:163-176.

GfE (Gesellschaft für Ernährungsphysiologie). 2001. Energie- und Nährstoffbedarf landwirtschaftlicher Nutztiere, No. 8: Empfehlungen zur Energie- und Nährstoffversorgung der Milchkühe und Aufzuchtrinder [Energy and nutrient requirements of farm animals, No. 8: Recommendations for the supply of energy and nutrients to dairy cows and heifers]. DLG-Verlag.

GfE (Gesellschaft für Ernährungsphysiologie). 2008. New equations for predicting metabolisable energy of grass and maize products for ruminants. Proc. Soc. Nutr. Physiol. 17:191-198.

GfE (Gesellschaft für Ernährungsphysiologie). 2009. New equations for predicting metabolisable energy of compound feeds for cattle. Proc. Soc. Nutr. Physiol. 18:143-146.

Greger, M., M. Schlienz, and P. C. Benito Martin. 2018. Kohlenhydratanalyse beim Gärprozess mit einer angepassten Anthron-Methode [Carbohydrate analysis during fermentation using an adapted anthrone method]. Landtechnik 73:81-94.

Gruber, L., F. J. Schwarz, D. Erdin, B. Fischer, H. Spiekers, H. Steingaß, U. Meyer, A. Chassot, T. Jilg, A. Obermaier, and T. Guggenberger. 2005. Vorhersage der Futteraufnahme von Milchkühen - Datenbasis von 10 Forschungs- und Universitätsinstituten Deutschlands, Österreichs und der Schweiz [Prediction of feed intake of dairy cows - Database of 10 research and university insti- tutes in Germany, Austria and Switzerland]. VDLUFA-Schriftenr. 60:484-504

Jahn, E., and P. T. Chandler. 1976. Performance and nutrient requirements of calves fed varying percentages of protein and fiber. J. Anim. Sci. 42:724-735. https://doi.org/10.2527/jas1976.423724x.

Khan, M. A., A. Bach, D. M. Weary, and M. A. G. von Keyserlingk. 2016. Invited review: Transitioning from milk to solid feed in dairy heifers. J. Dairy Sci. 99:885-902. https://doi.org/10.3168/jds.2015 $-9975$.

Khan, M. A., V. T. Burggraaf, B. Thomson, P. Muir, K. Lowe, J. Koolaard, A. Heiser, S. Leath, and S. McCoard. 2020. Feeding forage or concentrates early in life influences rumen fermentation, metabolic response, immune function and growth of Wagyu $\times$ Friesian calves. Anim. Prod. Sci. 60:1418-1428. https://doi.org/10.1071/ AN18636.

Khan, M. A., D. M. Weary, and M. A. G. von Keyserlingk. 2011. Hay intake improves performance and rumen development of calves fed higher quantities of milk. J. Dairy Sci. 94:3547-3553. https://doi .org/10.3168/jds.2010-3871.

Kirchgessner, M., F. X. Roth, F. J. Schwarz, and G. I. Stangl. 2008. Tierernährung [Animal Nutrition]. Vol. 12., rev. ed. DLG-Verlags$\mathrm{GmbH}$.

Kleefisch, M.-T., Q. Zebeli, E. Humer, I. Kröger, P. Ertl, and F. Klevenhusen. 2017. Effects of the replacement of concentrate and fibrerich hay by high-quality hay on chewing, rumination and nutrient digestibility in non-lactating Holstein cows. Arch. Anim. Nutr. 71:21-36. https://doi.org/10.1080/1745039X.2016.1253227.

Klevenhusen, F., M.-T. Kleefisch, and Q. Zebeli. 2019. Feeding hay rich in water-soluble carbohydrates improves ruminal $\mathrm{pH}$ without affecting rumination and systemic health in early lactation dairy cows. J. Anim. Physiol. Anim. Nutr. (Berl.) 103:466-476. https:// doi.org/10.1111/jpn.13051.

Klevenhusen, F., R. M. Petri, M.-T. Kleefisch, R. Khiaosa-ard, B. U. Metzler-Zebeli, and Q. Zebeli. 2017. Changes in fibre-adherent and fluid-associated microbial communities and fermentation profiles in the rumen of cattle fed diets differing in hay quality and concentrate amount. FEMS Microbiol. Ecol. 93. https://doi.org/10 $.1093 / \mathrm{femsec} / \mathrm{fix} 100$

Klevenhusen, F., and Q. Zebeli. 2021. A review on the potentials of using feeds rich in water-soluble carbohydrates to enhance rumen health and sustainability of dairy cattle production. J. Sci. Food Agric. 101:5737-5746. https://doi.org/10.1002/jsfa.11358.

Klingler, A., A. Schaumberger, F. Vuolo, L. B. Kalmár, and E. M. Pötsch. 2020. Comparison of direct and indirect determination of leaf area index in permanent grassland. PFG-J. Photogramm. Remote Sens. Geoinf. Sci. 88:369-378.

Kononoff, P. J., A. J. Heinrichs, and D. R. Buckmaster. 2003. Modification of the Penn State forage and total mixed ration particle separator and the effects of moisture content on its measurements. J. Dairy Sci. 86:1858-1863. https://doi.org/10.3168/jds.S0022 -0302(03)73773-4.

Laarman, A. H., and M. Oba. 2011. Short communication: Effect of calf starter on rumen $\mathrm{pH}$ of Holstein dairy calves at weaning. J. Dairy Sci. 94:5661-5664. https://doi.org/10.3168/jds.2011-4273.

Lee, M. R. F., L. J. Harris, J. M. Moorby, M. O. Humphreys, M. K. Theodorou, J. C. MacRae, and N. D. Scollan. 2002. Rumen metabolism and nitrogen flow to the small intestine in steers offered Lolium perenne containing different levels of water-soluble carbohydrate. Anim. Sci. 74:587-596. https://doi.org/10.1017/ S1357729800052747.

Lee, M. R. F., E. L. Jones, J. M. Moorby, M. O. Humphreys, M. K. Theodorou, and N. D. Scollan. 2001. Production responses from lambs grazed on Lolium perenne selected for an elevated watersoluble carbohydrate concentration. Anim. Res. 50:441-449. https: //doi.org/10.1051/animres:2001106.

Liepa, G. U., D. C. Beitz, and J. R. Linder. 1978. Cholesterol synthesis in ruminating and nonruminating goats. J. Nutr. 108:535-543. https://doi.org/10.1093/jn/108.3.535.

Mertens, D. R. 1994. Regulation of forage intake. Pages 450-493 in Forage Quality, Evaluation, and Utilization. G. C. J. Fahey, M. Collins, D. R. Mertens, and L. E. Moser, ed. American Society 
of Agronomy Inc., Crop Science Society of America Inc., and Soil Science of America, Inc.

Miller-Cushon, E. K., R. Bergeron, K. E. Leslie, G. J. Mason, and T. J. DeVries. 2013. Effect of early exposure to different feed presentations on feed sorting of dairy calves. J. Dairy Sci. 96:4624-4633. https://doi.org/10.3168/jds.2013-6670.

Miller-Cushon, E. K., and T. J. DeVries. 2015. Invited review: Development and expression of dairy calf feeding behaviour. Can. J. Anim. Sci. 95:341-350. https://doi.org/10.4141/cjas-2014-163.

Miller-Cushon, E. K., and T. J. DeVries. 2017. Feed sorting in dairy cattle: Causes, consequences, and management. J. Dairy Sci. 100:4172-4183. https://doi.org/10.3168/jds.2016-11983.

Miller-Cushon, E. K., M. Terré, T. J. DeVries, and A. Bach. 2014 The effect of palatability of protein source on dietary selection in dairy calves. J. Dairy Sci. 97:4444-4454. https://doi.org/10.3168/ jds.2013-7816.

Mitchell, L. K., and A. J. Heinrichs. 2020. Increasing grass hay inclusion level on weaned dairy calf growth, intake, digestibility, and ruminal fermentation. J. Dairy Sci. 103:9012-9023. https://doi.org/ $10.3168 /$ jds.2020-18596.

Mohri, M., K. Sharifi, and S. Eidi. 2007. Hematology and serum biochemistry of Holstein dairy calves: Age related changes and comparison with blood composition in adults. Res. Vet. Sci. 83:30-39. https://doi.org/10.1016/j.rvsc.2006.10.017.

Moorby, J. M., R. T. Evans, N. D. Scollan, J. C. MacRae, and M. K. Theodorou. 2006. Increased concentration of water-soluble carbohydrate in perennial ryegrass (Lolium perenne L.). Evaluation in dairy cows in early lactation. Grass Forage Sci. 61:52-59. https:// doi.org/10.1111/j.1365-2494.2006.00507.x.

Omidi-Mirzaei, H., A. Azarfar, M. Mirzaei, A. Kiani, and M. H. Ghaffari. 2018. Effects of forage source and forage particle size as a free-choice provision on growth performance, rumen fermentation, and behavior of dairy calves fed texturized starters. J. Dairy Sci. 101:4143-4157. https://doi.org/10.3168/jds.2017-13990.

Opsomer, G., M. Van Eetvelde, M. Kamal, and A. Van Soom. 2016. Epidemiological evidence for metabolic programming in dairy cattle. Reprod. Fertil. Dev. 29:52-57. https://doi.org/10.1071/ RD16410.

Petri, R. M., T. Schwaiger, G. B. Penner, K. A. Beauchemin, R. J. Forster, J. J. McKinnon, and T. A. McAllister. 2013. Characterization of the core rumen microbiome in cattle during transition from forage to concentrate as well as during and after an acidotic challenge. PLoS One 8:e83424. https://doi.org/10.1371/journal .pone.0083424

Plaizier, J. C., E. Khafipour, S. Li, G. N. Gozho, and D. O. Krause. 2012. Subacute ruminal acidosis (SARA), endotoxins and health consequences. Anim. Feed Sci. Technol. 172:9-21. https://doi.org/ 10.1016/j.anifeedsci.2011.12.004.

Poier, G., Q. Zebeli, and G. Terler. 2020. Effect of hay quality with or without concentrate supplementation on ruminal dynamic $\mathrm{pH}$ changes from birth to weaning in rearing calves. Proc. Soc. Nutr. Physiol. 30:134

Quigley, J. D. 2019. Symposium review: Re-evaluation of National Research Council energy estimates in calf starters. J. Dairy Sci. 102:3674-3683. https://doi.org/10.3168/jds.2018-15367.

Quigley, J. D., W. Hu, J. R. Knapp, T. S. Dennis, F. X. Suarez-Mena, and T. M. Hill. 2019. Estimates of calf starter energy affected by consumption of nutrients. 2. Effect of changing digestion on energy content in calf starters. J. Dairy Sci. 102:2242-2253. https://doi .org/10.3168/jds.2018-15354.

Sander, E. G., R. G. Warner, H. N. Harrison, and J. K. Loosli. 1959. The stimulatory effect of sodium butyrate and sodium propionate on the development of rumen mucosa in the young calf. J. Dairy Sci. 42:1600-1605. https://doi.org/10.3168/jds.S0022 $-0302(59) 90772-6$
Silva, A. L., T. J. DeVries, L. O. Tedeschi, and M. I. Marcondes. 2019. Development of equations, based on milk intake, to predict starter feed intake of preweaned dairy calves. Animal 13:83-89. https:// doi.org/10.1017/S1751731118000666.

Sniffen, C. J., J. D. O'Connor, P. J. Van Soest, D. G. Fox, and J. B. Russell. 1992. A net carbohydrate and protein system for evaluating cattle diets: II. Carbohydrate and protein availability. J. Anim. Sci. 70:3562-3577. https://doi.org/10.2527/1992.70113562x.

Steele, M. A., G. Vandervoort, O. AlZahal, S. E. Hook, J. C. Matthews, and B. W. McBride. 2011. Rumen epithelial adaptation to high-grain diets involves the coordinated regulation of genes involved in cholesterol homeostasis. Physiol. Genomics 43:308-316. https://doi.org/10.1152/physiolgenomics.00117.2010.

Suárez, B. J., C. G. Van Reenen, N. Stockhofe, J. Dijkstra, and W. J. J. Gerrits. 2007. Effect of roughage source and roughage to concentrate ratio on animal performance and rumen development in veal calves. J. Dairy Sci. 90:2390-2403. https://doi.org/10.3168/ jds.2006-524.

Sutton, J. D., A. D. McGilliard, M. Richard, and N. L. Jacobson. 1963. Functional development of rumen mucosa. II. Metabolic activity. J. Dairy Sci. 46:530-537. https://doi.org/10.3168/jds.S0022 -0302(63)89090-6.

Terré, M., L. Castells, M. A. Khan, and A. Bach. 2015. Interaction between the physical form of the starter feed and straw provision on growth performance of Holstein calves. J. Dairy Sci. 98:1101-1109. https://doi.org/10.3168/jds.2014-8151.

Terré, M., E. Pedrals, A. Dalmau, and A. Bach. 2013. What do preweaned and weaned calves need in the diet: A high fiber content or a forage source? J. Dairy Sci. 96:5217-5225. https://doi.org/10 $.3168 /$ jds.2012-6304.

VDLUFA (Verband Deutscher Landwirtschaftlicher Untersuchungsund Forschungsanstalten). 2012. Handbuch der landwirtschaftlichen Versuchs- und Untersuchungsmethodik (VDLUFA-Methodenbuch), Bd. III. Die chemische Untersuchung von Futtermitteln [Manual of agricultural methods of testing and analysis (VDLUFA methods book), Volume III - Feed analysis]. VDLUFA-Verlag.

Wetzels, S. U., E. Mann, B. U. Metzler-Zebeli, P. Pourazad, M. Qumar, F. Klevenhusen, B. Pinior, M. Wagner, Q. Zebeli, and S. SchmitzEsser. 2016. Epimural indicator phylotypes of transiently-induced subacute ruminal acidosis in dairy cattle. Front. Microbiol. 7:274. https://doi.org/10.3389/fmicb.2016.00274.

Yemm, E. W., and A. J. Willis. 1954. The estimation of carbohydrates in plant extracts by anthrone. Biochem. J. 57:508-514. https://doi .org/10.1042/bj0570508.

Yu, K., F. Canalias, D. Solà-Oriol, L. Arroyo, R. Pato, Y. Saco, M. Terré, and A. Bassols. 2019. Age-related serum biochemical reference intervals established for unweaned calves and piglets in the post-weaning period. Front. Vet. Sci. 6:123. https://doi.org/10 $.3389 /$ fvets.2019.00123.

Zebeli, Q., and B. U. Metzler-Zebeli. 2012. Interplay between rumen digestive disorders and diet-induced inflammation in dairy cattle. Res. Vet. Sci. 93:1099-1108. https://doi.org/10.1016/j.rvsc.2012 .02 .004 .

\section{ORCIDS}

G. Terler $\odot$ https://orcid.org/0000-0001-8881-6407

G. Poier $\odot$ https://orcid.org/0000-0002-0286-9039

F. Klevenhusen () https://orcid.org/0000-0001-6015-5459

Q. Zebeli $\odot$ https://orcid.org/0000-0001-5188-9004 